\title{
The effect of household storage tanks/ vessels and user practices on the quality of water: a systematic review of literature
}

\author{
Musa Manga ${ }^{1,2,3^{*}}$, Timothy G. Ngobi ${ }^{1}$, Lawrence Okeny ${ }^{1}$, Pamela Acheng ${ }^{1}$, Hidaya Namakula',
} Elizabeth Kyaterekera ${ }^{3}$, Irene Nansubuga ${ }^{4}$ and Nathan Kibwami ${ }^{1}$

\begin{abstract}
Background: Household water storage remains a necessity in many communities worldwide, especially in the developing countries. Water storage often using tanks/vessels is envisaged to be a source of water contamination, along with related user practices. Several studies have investigated this phenomenon, albeit in isolation. This study aimed at developing a systematic review, focusing on the impacts of water storage tank/vessel features and user practices on water quality.
\end{abstract}

Methods: Database searches for relevant peer-reviewed papers and grey literature were done. A systematic criterion was set for the selection of publications and after scrutinizing 1106 records, 24 were selected. These were further subjected to a quality appraisal, and data was extracted from them to complete the review.

Results and discussion: Microbiological and physicochemical parameters were the basis for measuring water quality in storage tanks or vessels. Water storage tank/vessel material and retention time had the highest effect on stored water quality along with age, colour, design, and location. Water storage tank/vessel cleaning and hygiene practices like tank/vessel covering were the user practices most investigated by researchers in the literature reviewed and they were seen to have an impact on stored water quality.

Conclusions: There is evidence in the literature that storage tanks/vessels, and user practices affect water quality. Little is known about the optimal tank/vessel cleaning frequency to ensure safe drinking water quality. More research is required to conclusively determine the best matrix of tank/vessel features and user practices to ensure good water quality.

Keywords: Water quality, Water contamination, Water storage tank/vessel, Water storage tank/vessel features, Water users practices

\section{Highlights}

1. Tank/vessel material and retention time of water most affect the water quality of stored water.

2. Cleaning of tank/vessel improves the microbiological and physicochemical quality of stored water.

\footnotetext{
*Correspondence: musamanga@cedat.mak.ac.ug; mmanga@email.unc.edu

${ }^{3}$ Department of Civil Engineering, Faculty of Engineering, Ndejje

University, P.O. Box 7088, Kampala, Uganda

Full list of author information is available at the end of the article
}

3. The optimal tank/vessel cleaning frequency to ensure good drinking water quality is not defined in literature.

\section{Background}

Sustainable Development Goal, Target 6.1, addresses universal and equitable access to safe and affordable drinking water, implying that it is geared towards ensuring that all people in the world can access water in the right amounts, quality, and cost, in a sustainable manner. 
A 2019 report by the World Bank indicates that the proportion of the world's population using safely managed drinking water services has been increasing, even before the adoption of the 2030 Sustainable Development Goals (SDG). However, despite these efforts, the world still faces an invisible crisis of poor water quality, which threatens amongst other things, the wellbeing of humans (World Bank 2019). Water of both acceptable quality and sufficient quantity, is critical for proper human health and wellbeing. For many years, attention has been focused on both access to and quality of water, but while access to safe water has significantly improved worldwide, quality appears to be further declining and it has been deteriorating more than proportionally to the economic and population growth (Boretti and Rosa 2019). Good quality water is one that has acceptable chemical, physical, biological, and radiological characteristics, based on local and widely-acceptable international standards, such as World Health Organization standards. The diminishing quality of water can be attributed to contamination at different points of the water supply system including distribution and storage (Al-Bahry et al. 2009, 2011). Although many organizations both local and international have been directing vast efforts towards the improvement of water quality, water contamination is still rampant. Contamination, whether directly or indirectly, by human or animal excreta, particularly faeces is the most common and widespread health risk associated with drinking water (Raju et al. 2011; Manga et al. 2020; Fleming et al. 2019).

Water storage, the main feature of the indirect cold water supply system (see Fig. 1), and many other unpiped water supply systems has for many years been identified as a source of contamination of domestic water. In fact, because of this, the kitchen sink in the indirect cold water supply system receives water directly from the mains, instead of the storage tank.

Household water storage is fraught with many challenges which ultimately result in compromising the quality of water (Nnaji et al. 2019). Water storage tanks do harbor several pathogens that cause different diseases and illnesses. Waterborne illnesses caused by bacteria found in contaminated household water storage tanks increases the risk of spreading waterborne diseases, and may lead to many infectious outbreaks (Khan and AlMadani 2016).

With the projection by the United Nations (2018) that nearly 6 billion people will be faced with clean water scarcity by 2050 (Boretti and Rosa 2019), there is a critical need to investigate sources of water contamination. Several studies many of which from the developing world, have investigated the impact of water storage on water quality. For instance, Schafer (2010), Ziadat
(2005), Mohanan et al. (2017) and Douhri et al. (2015) focused on the impacts of storage material on water quality while Holt (2005) and Agensi et al. (2019) focused on the impacts of user practices on stored household water quality. However, to date, there is no single study found in literature, that comprehensively reviewed tank features and user practices in relation to household water contamination factors. Having such comprehensive knowledge would aid further research and policy into mitigating the impact of storage on household water quality. This review, therefore, seeks to fill this gap by systematically reviewing literature to answer the following research questions: (1) What features of storage tanks/ vessels and user practices impact on household water quality? (2) How do the features of storage tanks/vessels and user practices affect household water quality? (3) What can be done to mitigate the effects of the storage tank/vessel features and user practices on water quality?

\section{Methods}

The methodology adopted included a systematic literature review approach in order to identify the most relevant articles to be included in the study, citation network analysis of the selected articles and a quality appraisal framework (Colicchia and Strozzi 2012; Anthonj et al. 2020; Venkataramanan et al. 2018).

\section{Search strategy}

Literature searches were conducted in ScienceDirect, PubMed, Scirus, and Web of Knowledge using the following search terms: "water quality in tanks" or "drinking water quality under indirect water supply" or "drinking water in storage tanks" or "domestic water" or "household water storage" or "water contamination in storage containers and vessels" or "domestic water contamination" or "contamination in tanks". The databases were selected because they were leading databases on scientific research. Searches were also conducted in the Google and Google Scholar search engines, where the first 50 hits were checked for potentially relevant papers.

On identifying some relevant papers, additional studies were obtained from the reference lists and their titles were used as search terms on Google and Google Scholar search engines, leading to databases from which related studies were found by choosing the "show similar studies" search option while searching the databases.

\section{Selection criteria}

Published peer reviewed papers and grey literature obtained from the comprehensive searches were considered eligible to be included in the review only if they met the following criteria: 


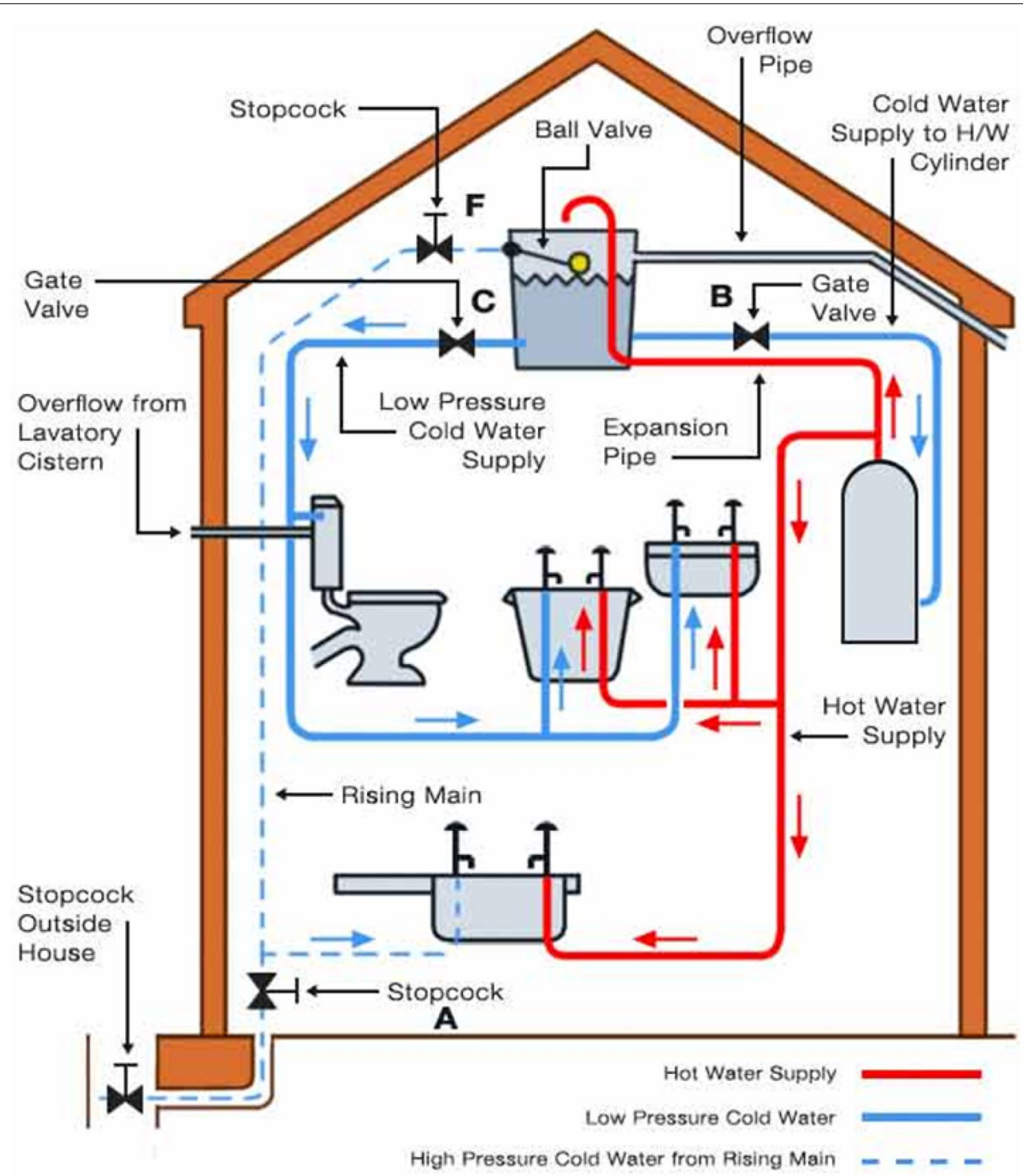

Fig. 1 Indirect cold water supply system (Doctor DIY 2021)

1. Reported on water quality in storage tanks, vessels, or containers in households;

2. Based on empirical research;

3. Published by Accredited Organizations;

4. Were written in English;

5. Published between 2000 and 2019.

Studies that did not meet the above criteria were excluded. Full texts of publications that met the criteria were retrieved and reviewed in detail by a group of reviewers for quality, assessment of bias, and relevance to study objectives.
The selection methodology process of records included in this study is as shown in Fig. 2. A total of 1091 records were obtained from peer-reviewed journal database searches using the search strategy mentioned in "Search strategy" Section. From web searches, a total of 15 records of grey literature related to the subject were found. There were 117 duplicate records and these were discarded. The remaining had their abstracts and executive summaries screened to check their eligibility to be included in the review. A total of 952 of the obtained records whose abstracts and executive summaries were scanned did not meet the criteria. These focused mainly on distribution 


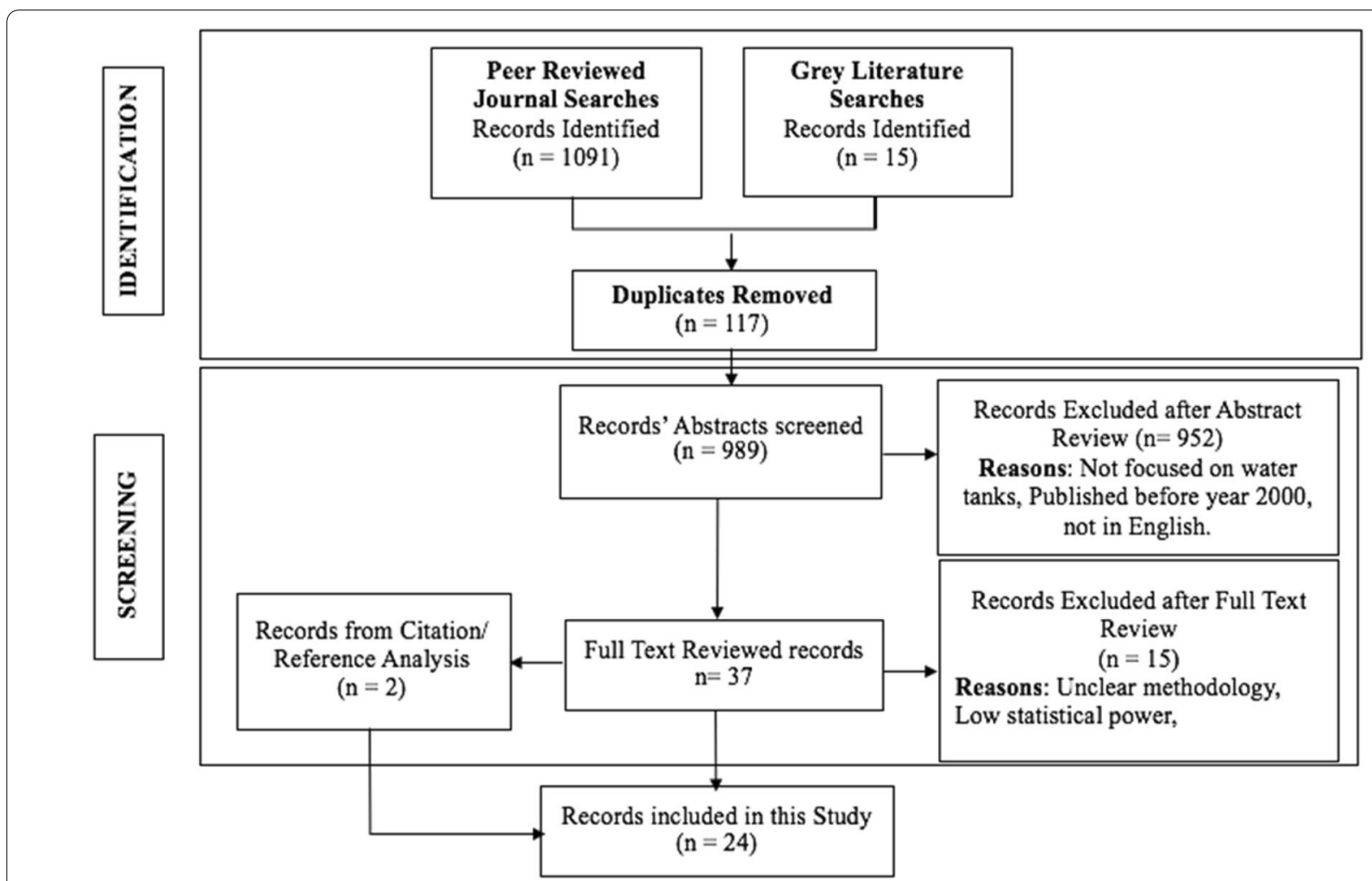

Fig. 2 Selection process

and sources of water rather than household tank storage, and on this premise they were eliminated. Therefore, 37 records were found eligible for full-text review but only 22 of them met the criteria for inclusion in the review. From citation network analysis, 2 relevant papers were found and included in the study. Eventually, 24 publications were purposively selected to be reviewed, based on the selection criteria discussed above.

\section{Data extraction}

Basing on the research questions, data was extracted from the selected records to complete this study. The data collected from the reviewed final sample of studies included: Storage tank or vessel features investigated; Household user practices in regards to the stored water and storage tanks; Geographical location of the studies; and Water quality indicators used (see Table 1; Fig. 3). This data was envisaged to be adequate for this review study.

After ensuring that all reviewers had a similar understanding of the data extraction process and the type of data that was targeted, they independently analyzed the records that were included in the final sample of literature and extracted the data. To check the consistency of the data, the reviewers maintained an online google sheet and google document such that all reviewers could highlight the discrepancies and inconsistencies in the data. All identified relationships in the final sample of studies or their supplementary materials were considered, whether established quantitatively or qualitatively. These were tabulated in a Microsoft Excel database for analysis.

\section{Quality appraisal}

To characterize the quality of the publications or records selected and included in this review, a framework was developed for quality appraisal and this framework was guided by previous studies (Venkataramanan et al. 2018; Jack et al. 2010; Heale and Twycross 2015; Loevinsohn 1990; Pluye et al. 2009; Puzzolo et al. 2013; Spencer et al. 2003; Thomas et al. 2004). The developed framework was used to assess the quality of reporting and bias in each of the literature publications included in the study. The framework enabled the reviewers to check the elaborateness of the objectives of each study, the context, methodology appropriateness, randomization, independence of data collection, the statistical significance of results for quantitative studies, subjection to external peer-reviewing, and the conclusion appropriateness. Each of these appraisal criteria was assigned a score between 0 and 2 and the total score to categorize 


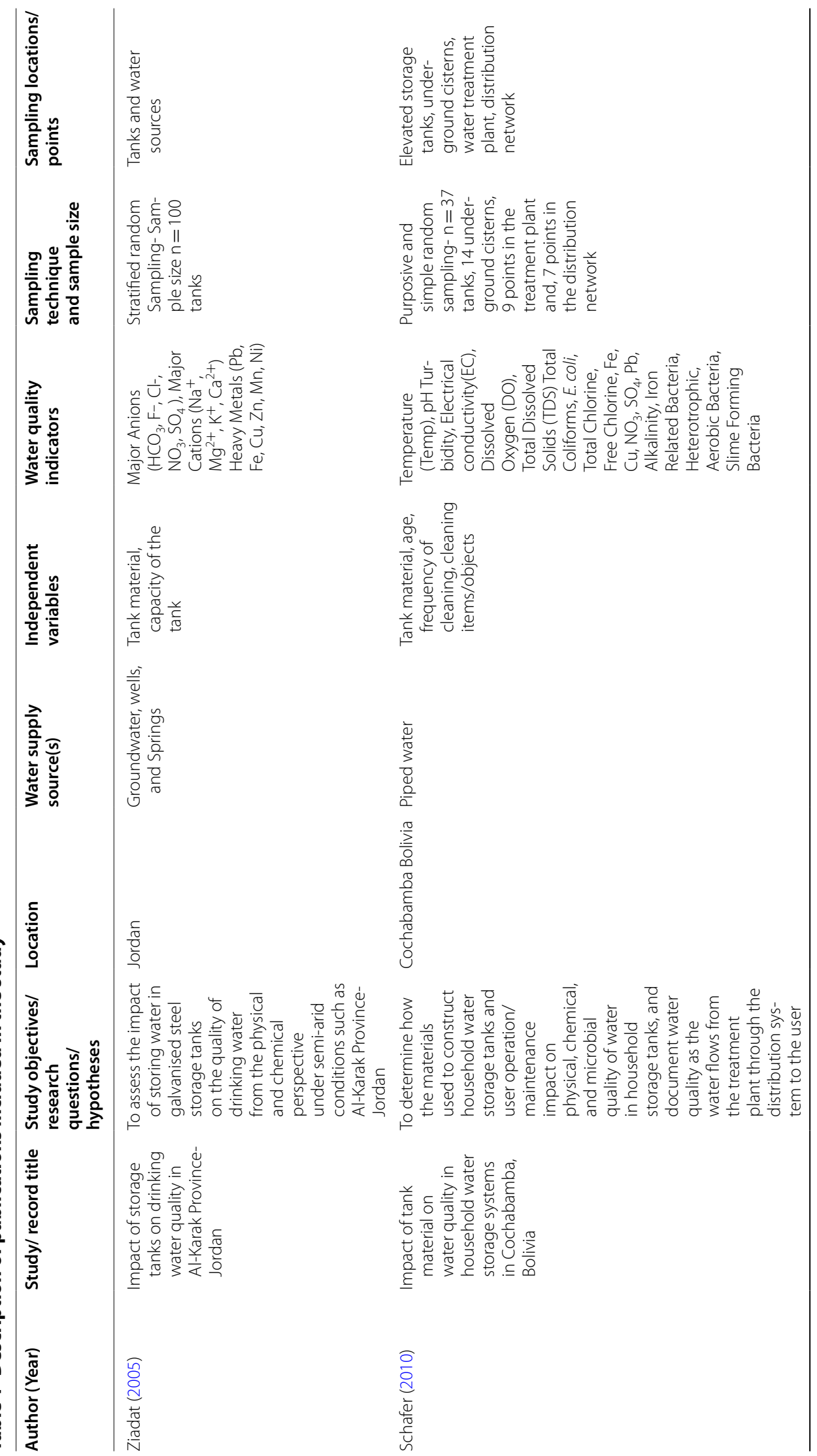




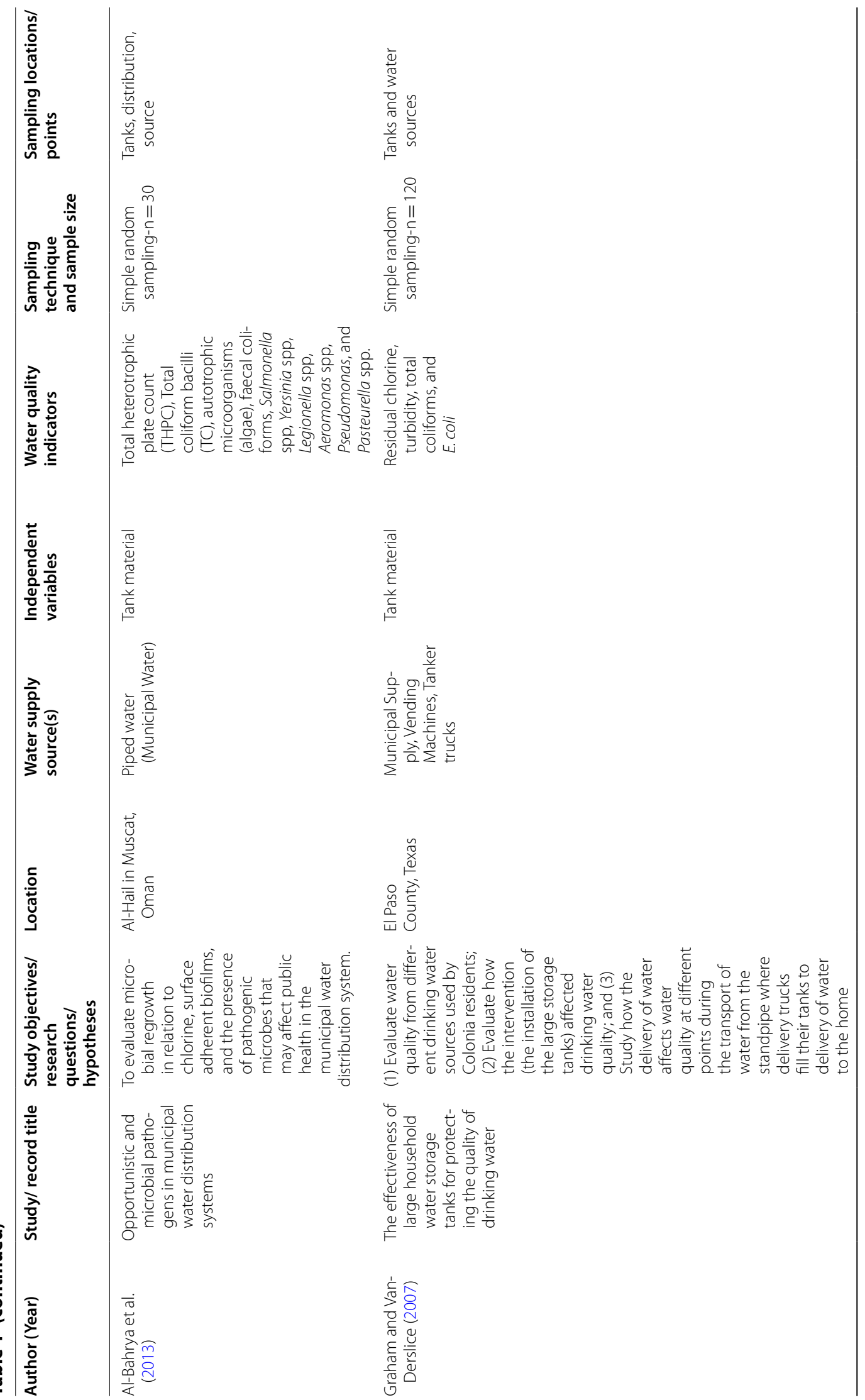




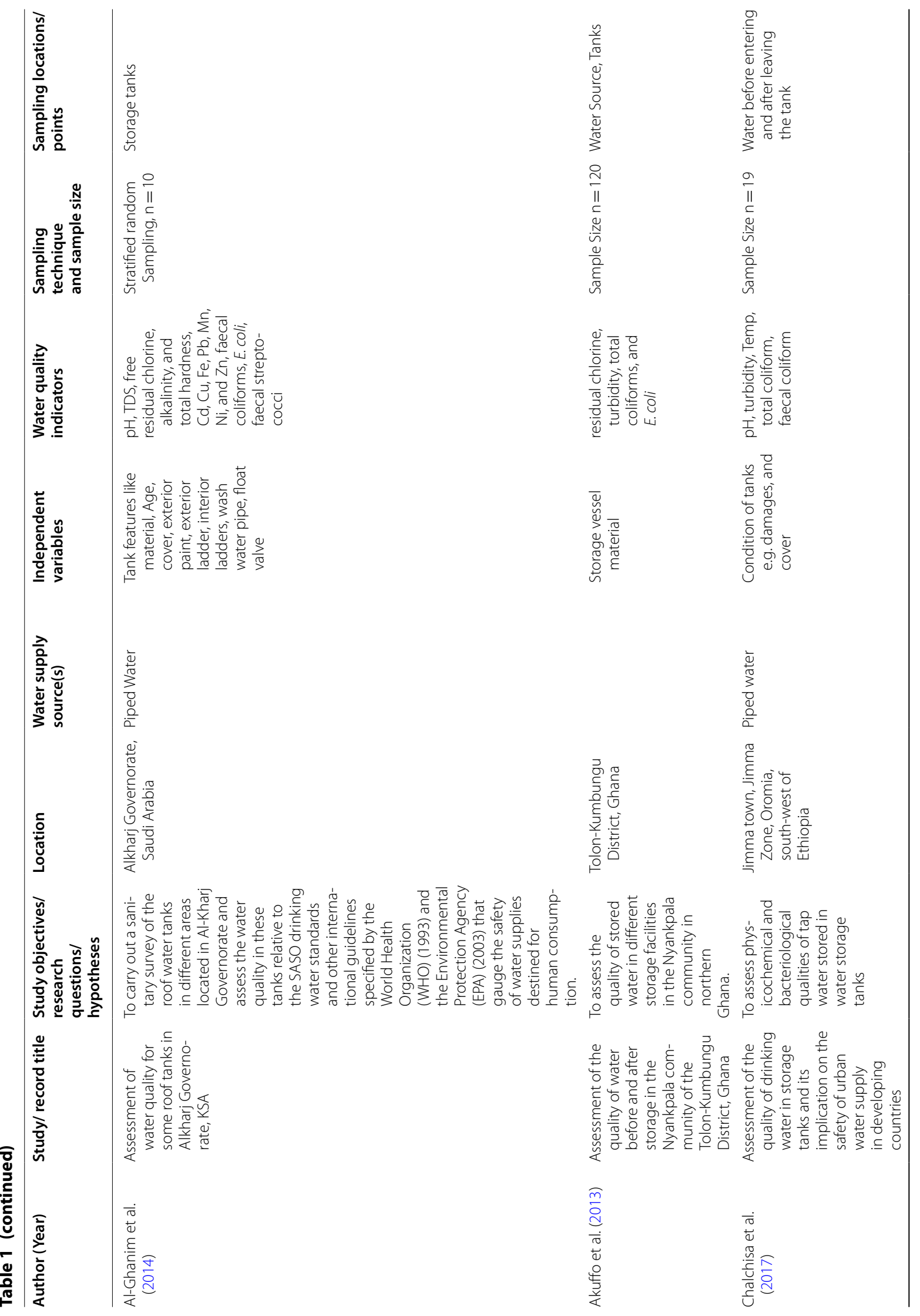




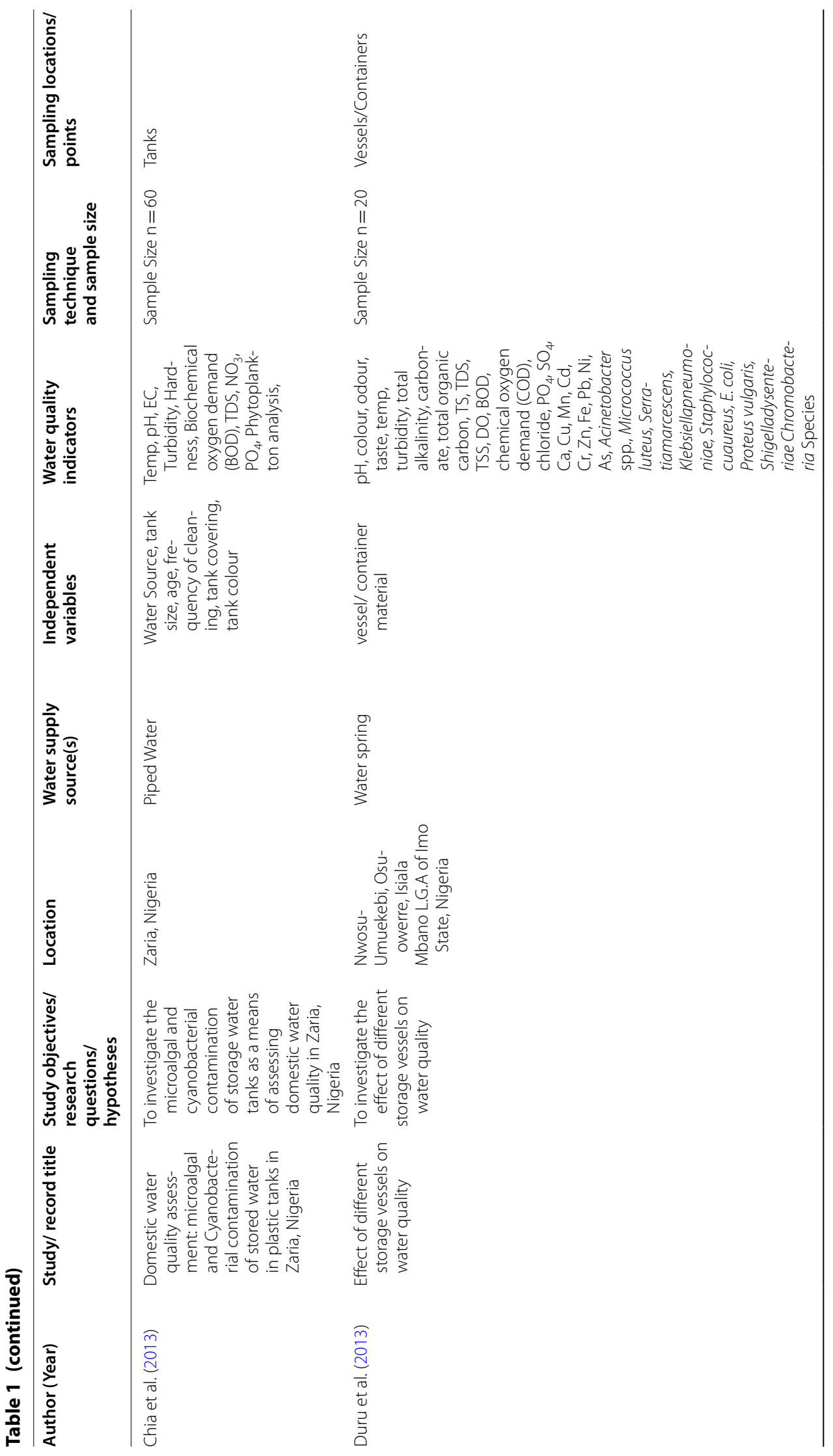




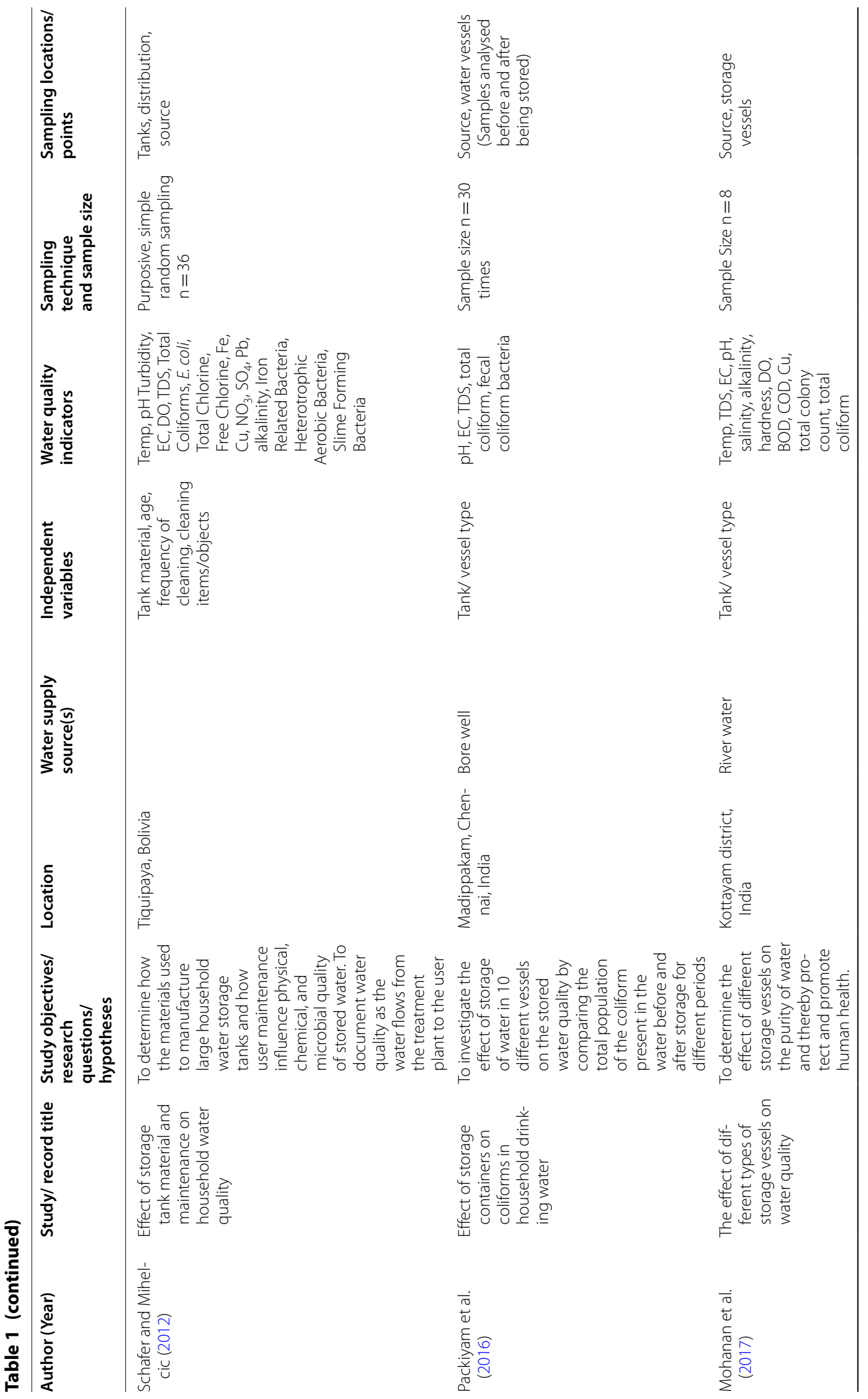




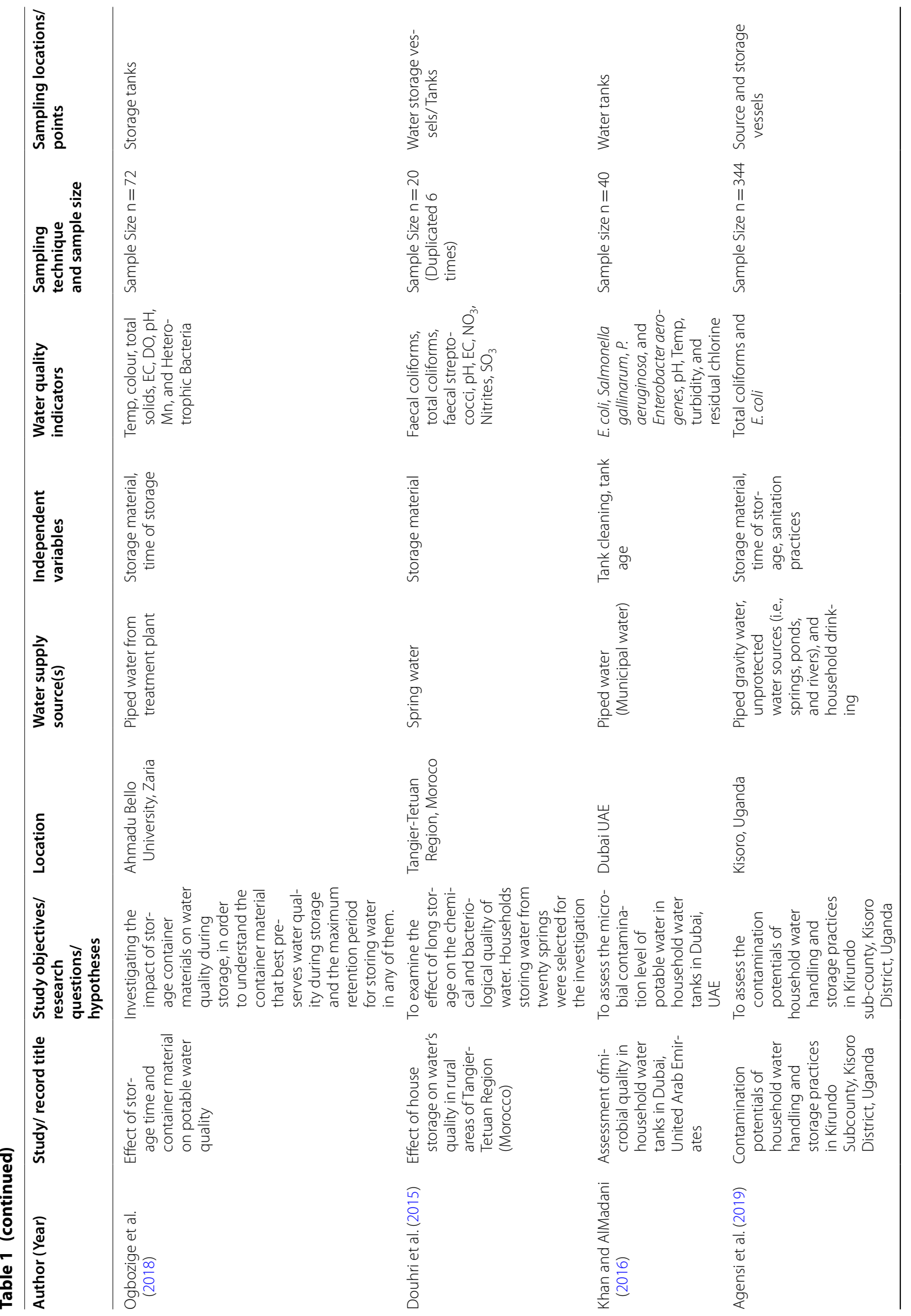




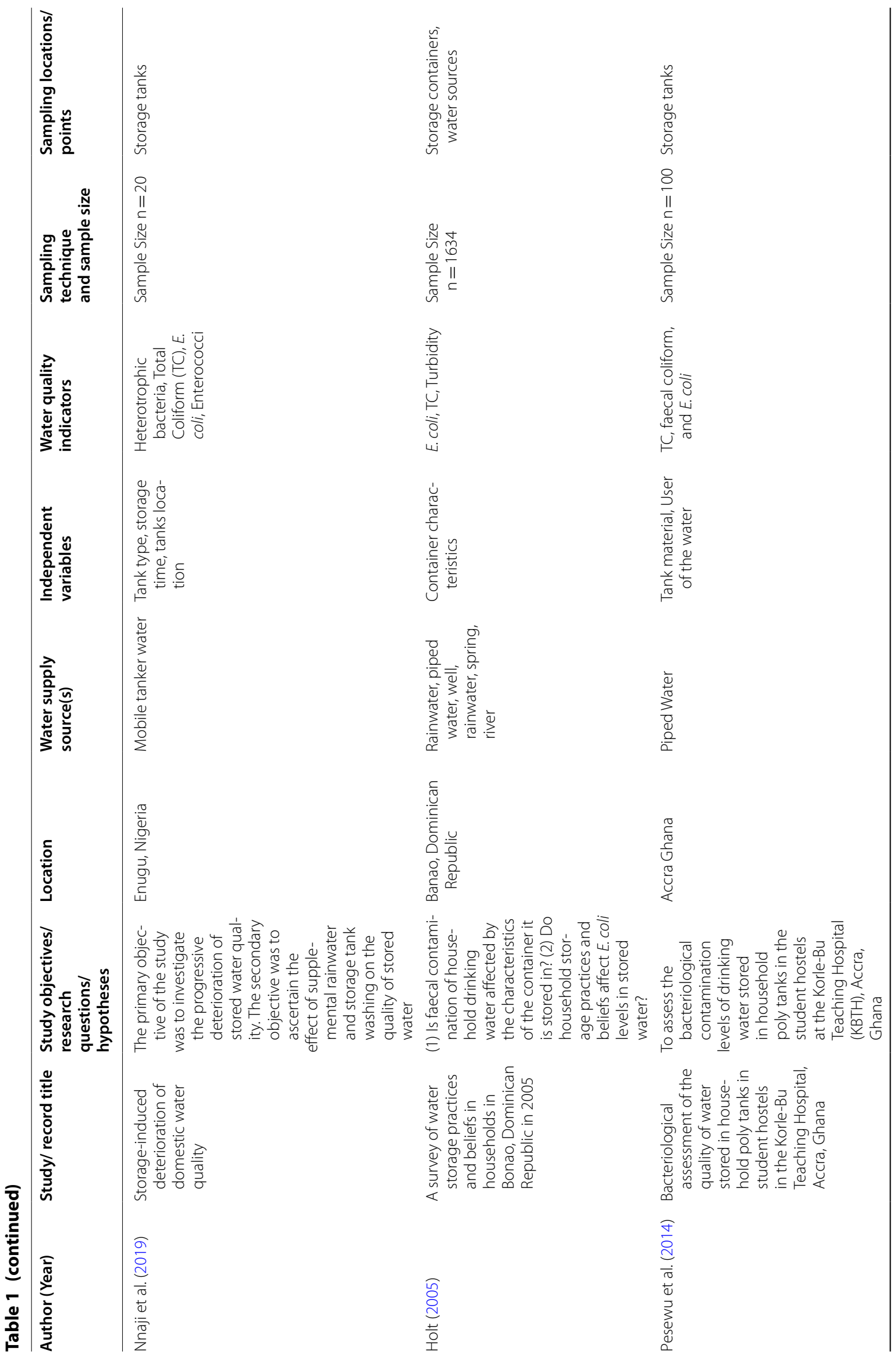




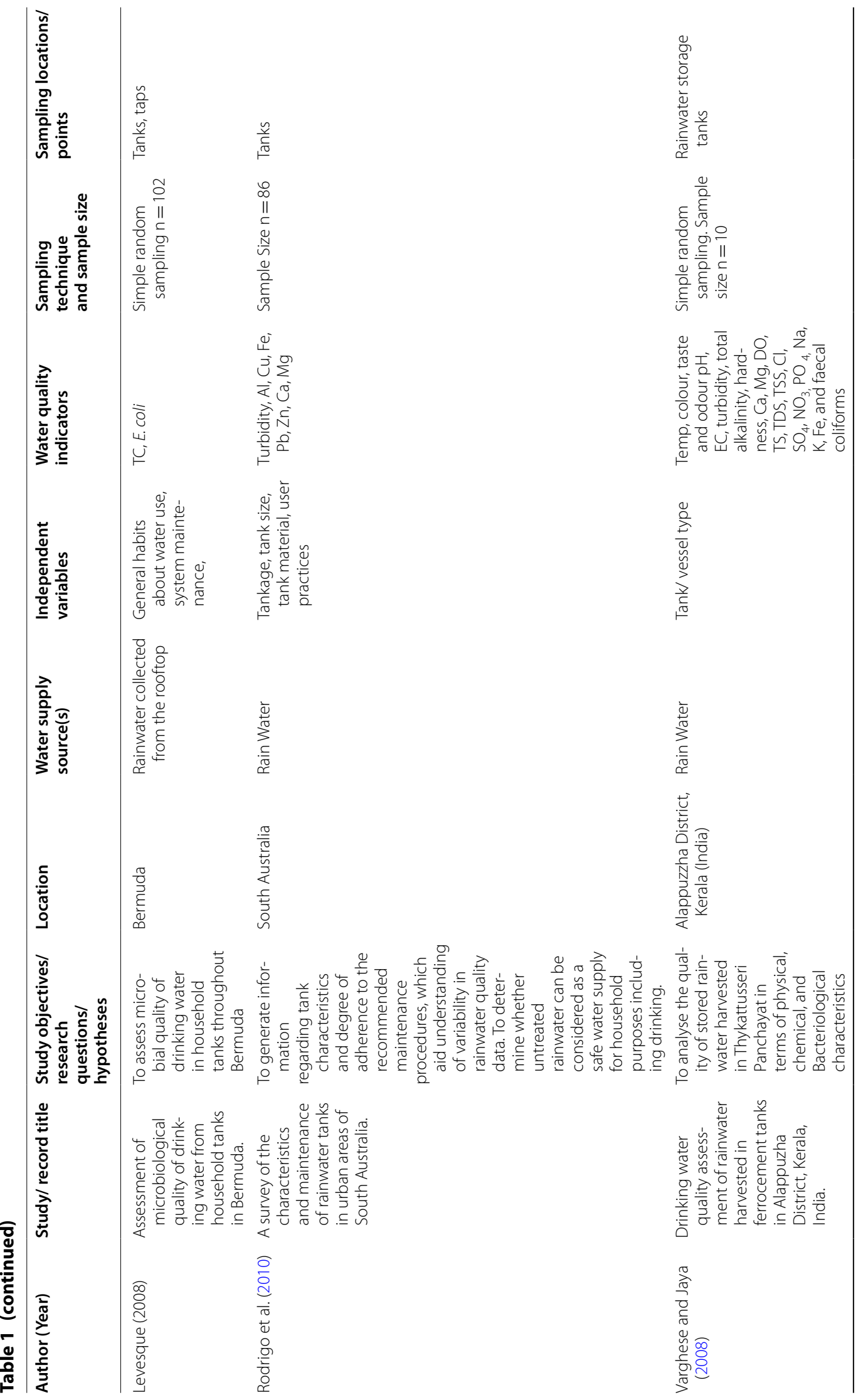




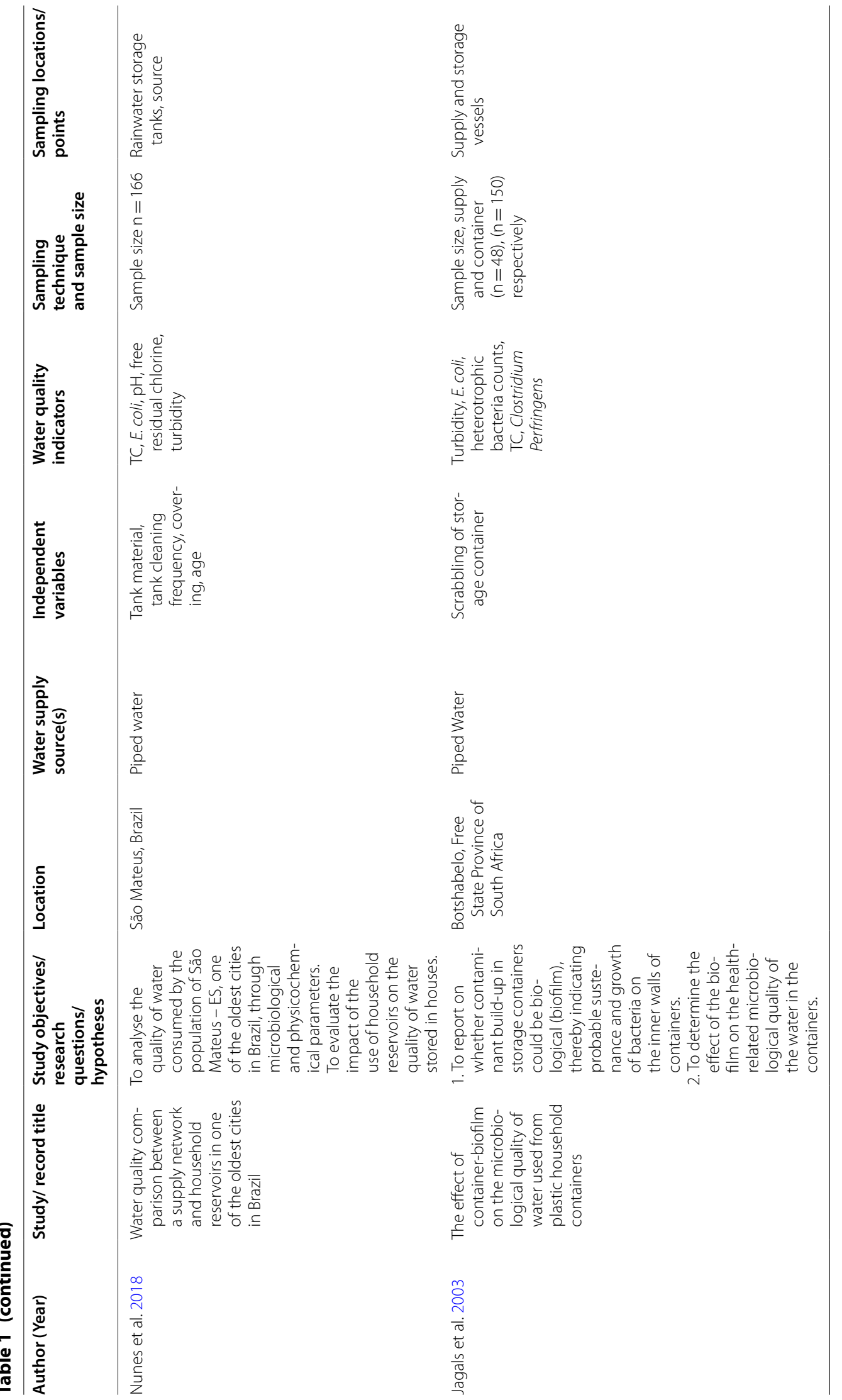




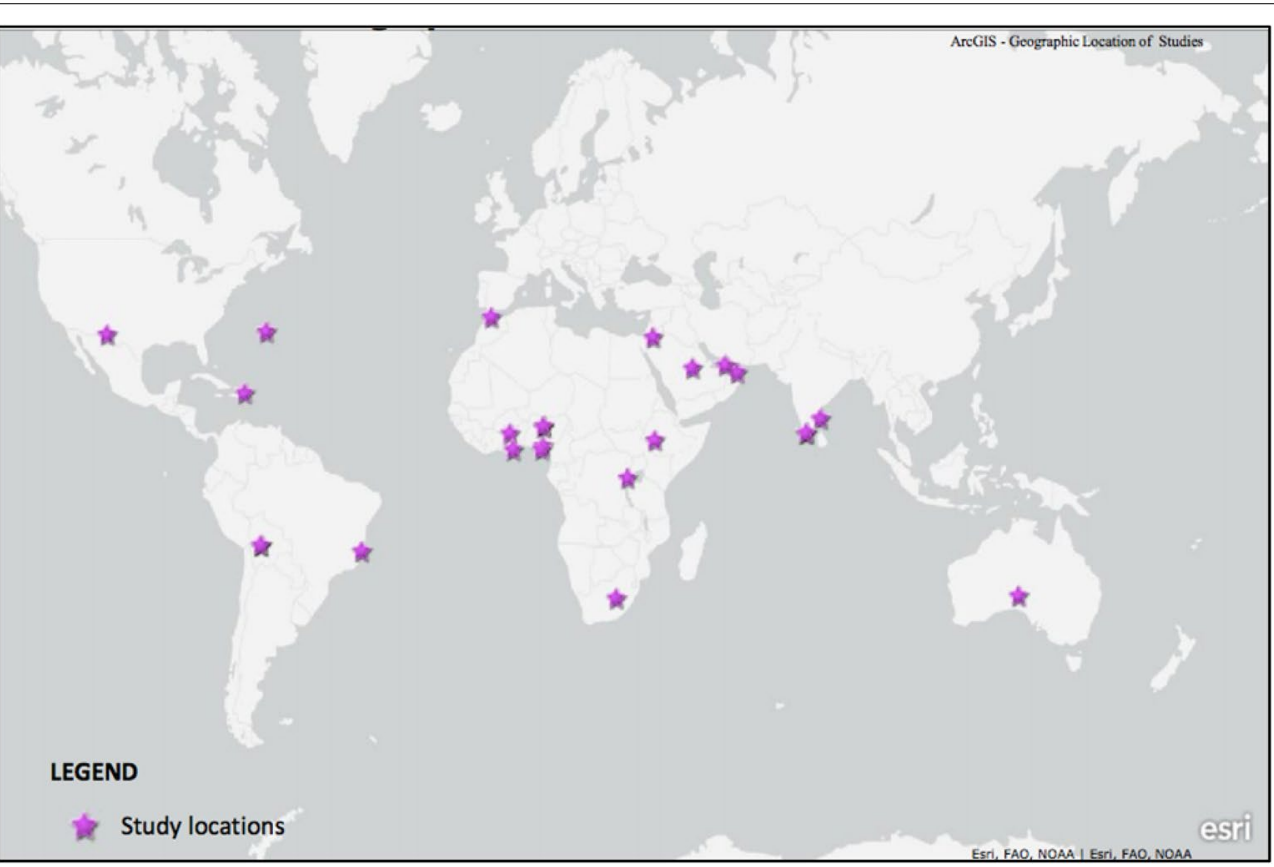

Fig. 3 Geographical distribution of the studies; the majority in developing countries

the overall risk of bias as high, moderate, or low was computed (Majuru et al. 2016). Table 2 shows the framework that was used for quality appraisal of the records that were included in the review. However, Table 3 shows the scoring and categorization of the overall quality of writing and risk of bias of each of the records that were included in the review. As can be seen, only one of the reviewed studies has a 'high' risk of bias because its overall quality of writing was low.

\section{Results and discussion}

Ninety- $2 \%$ of the literature reviewed was quite identical in terms of paper content arrangement, methodology, and gist. Twenty-two of reviewed studies conducted a

Table 2 Quality appraisal framework

\begin{tabular}{|c|c|}
\hline Category and criteria & Questions to guide quality appraisal \\
\hline \multicolumn{2}{|l|}{ Quality of reporting } \\
\hline Objectives & Were the objectives and purpose of the study or intervention described? \\
\hline Context & Was sufficient detail provided on the context and setting of the study or intervention? \\
\hline Study design & Was sufficient detail provided on the sampling approach? \\
\hline \multirow[t]{2}{*}{ Data collection } & Was sufficient detail provided on data collection methods and procedures? \\
\hline & Is there evidence of a systematic data collection process? \\
\hline Analysis & Was sufficient detail provided on analytical methods used in the study? \\
\hline \multicolumn{2}{|l|}{ Minimizing risk of bias } \\
\hline \multirow[t]{2}{*}{ Appropriateness of sampling } & Was sampling representative at the household level (did the survey represent the study population?) \\
\hline & Was sampling appropriate, given stated objectives? \\
\hline External peer review & Is there evidence of the document being subjected to external/independent review? \\
\hline \multicolumn{2}{|l|}{ Appropriateness of conclusion } \\
\hline Interpretations & Is there a discussion and interpretation of the main findings? \\
\hline Limitations & Were the study limitations described? \\
\hline Conclusions & Were stated conclusions and implications within the scope of the study design and data collection methods? \\
\hline
\end{tabular}

Adopted from (Venkataramanan et al. 2018; Jack et al. 2010; Harden 2010; Heale and Twycross 2015; Loevinsohn 1990; Pluye et al. 2009; Puzzolo et al. 2013; Spencer et al. 2003; Thomas et al. 2004; Anthonj et al. 2020) 


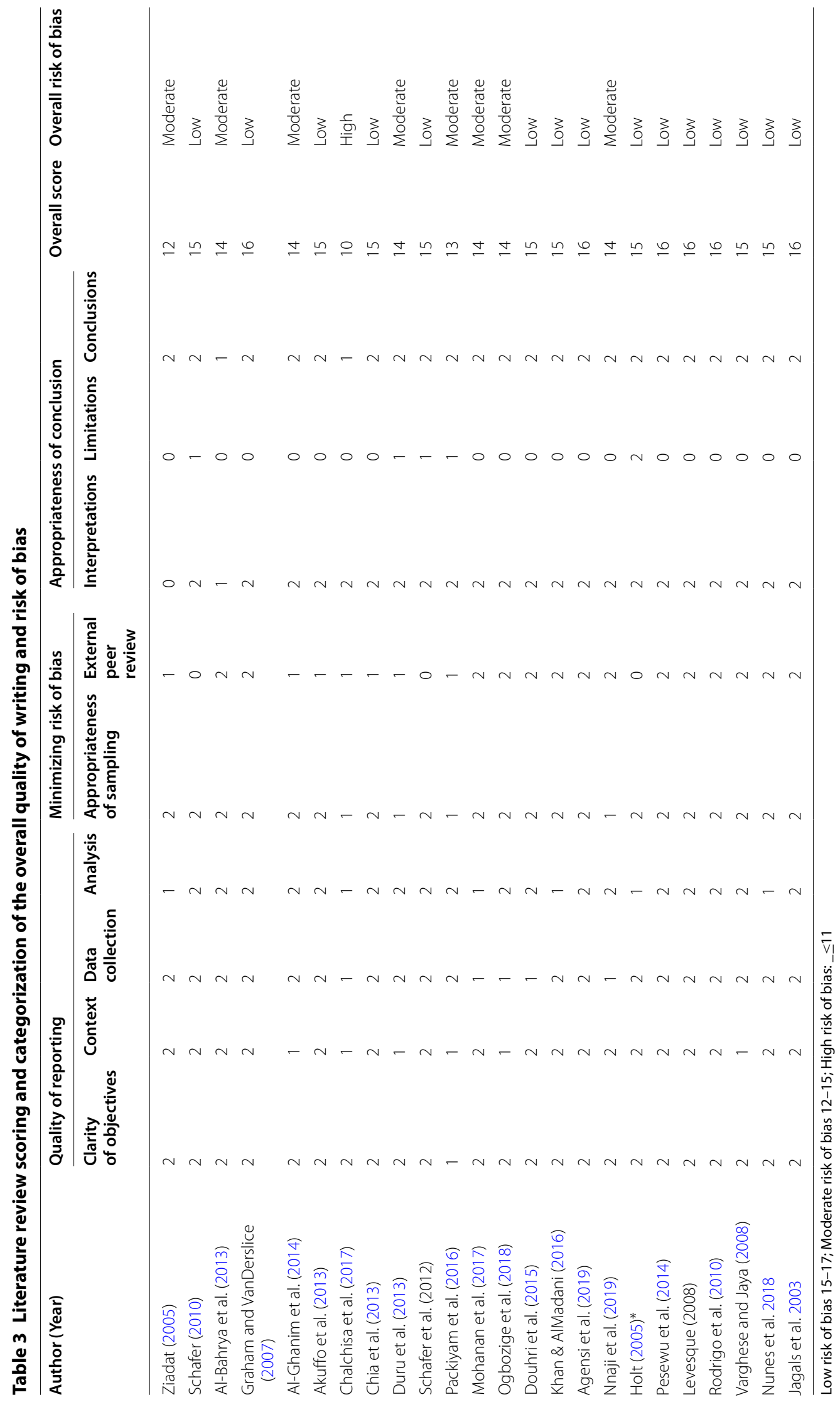


bacteriological and physicochemical analysis on water in storage tanks/vessels whereas 2 studies were specifically physicochemical analyses of tank/vessels water quality.

User practices like tank cleaning frequencies were investigated in a few of the reviewed research works. The studies reviewed were quantitative and qualitative from disciplines such as environmental engineering, water quality, and public health. To elaborate on how features and practices affect water quality, discussions of these phenomena were discussed in relation to the water quality indicators used in the studies. The results were presented under the following themes: Stored water contamination indicators; Water contamination in tanks/ vessels; and, Effects of user practices on water quality.

\section{Stored water contamination indicators}

The contamination indicators that were used to assess the quality of stored water in the reviewed research studies can be broadly categorized as biological and physicochemical.

\section{Biological indicators of stored water contamination}

The biological contamination indicators also known as the microbial or bacteriological indicators are widely used in the analysis of water quality in storage vessels. The use of bacteria as indicators of the sanitary quality of water, probably dates back to 1880 when Von Fritsch described Klebsiella pneumoniae and K. rhinoscleromatis as microorganisms characteristically found in human faeces (Geldreich 1978). In the publications reviewed in this study, multiple parameters were used to indicate microbial contamination, as shown in Fig. 4.

Total coliforms are a group of related bacteria that are often useful indicators of other pathogens in drinking water. They were the most used microbiological contamination indicator, as it was considered in several studies $(n=17)$ of those reviewed. This was followed by $E$. coli and faecal coliforms that were considered in $(n=12)$ and $(\mathrm{n}=8)$ studies, respectively. These are low numbers, considering the important role $E$. coli and faecal coliforms play in confirmation of faecal contamination.

Heterotrophic Aerobic Bacteria was another indicator considered by most of the reviewed studies. Some studies considered Klebsiella, Enterobacter, Serratia, Citrobacter, Tatumella, Escherichia vulneris (Al-Bahry et al. 2013), Salmonella spp., Legionella spp., Yersinia spp., Aeromonas spp., Pseudomonas, Pasteurella spp. (Duru et al. 2013), Slime Forming Bacteria, Iron Related Bacteria (Schafer and Mihelcic 2012), and phytoplankton species (Duru et al. 2013) as the other indicators of microbial contamination.

Overall, the choices of indicators of microbial contamination appeared to be in line with WHO's guidelines for water sampling and analysis, which require testing for indicators of faecal contamination as a minimum requirement. E. coli and faecal coliforms are the best indicators of faecal contamination because they confirm the presence of faecal matter, which are considered to pose the greatest risk to human health. Salmonella typhi., a bacterium that causes typhoid fever; a very common

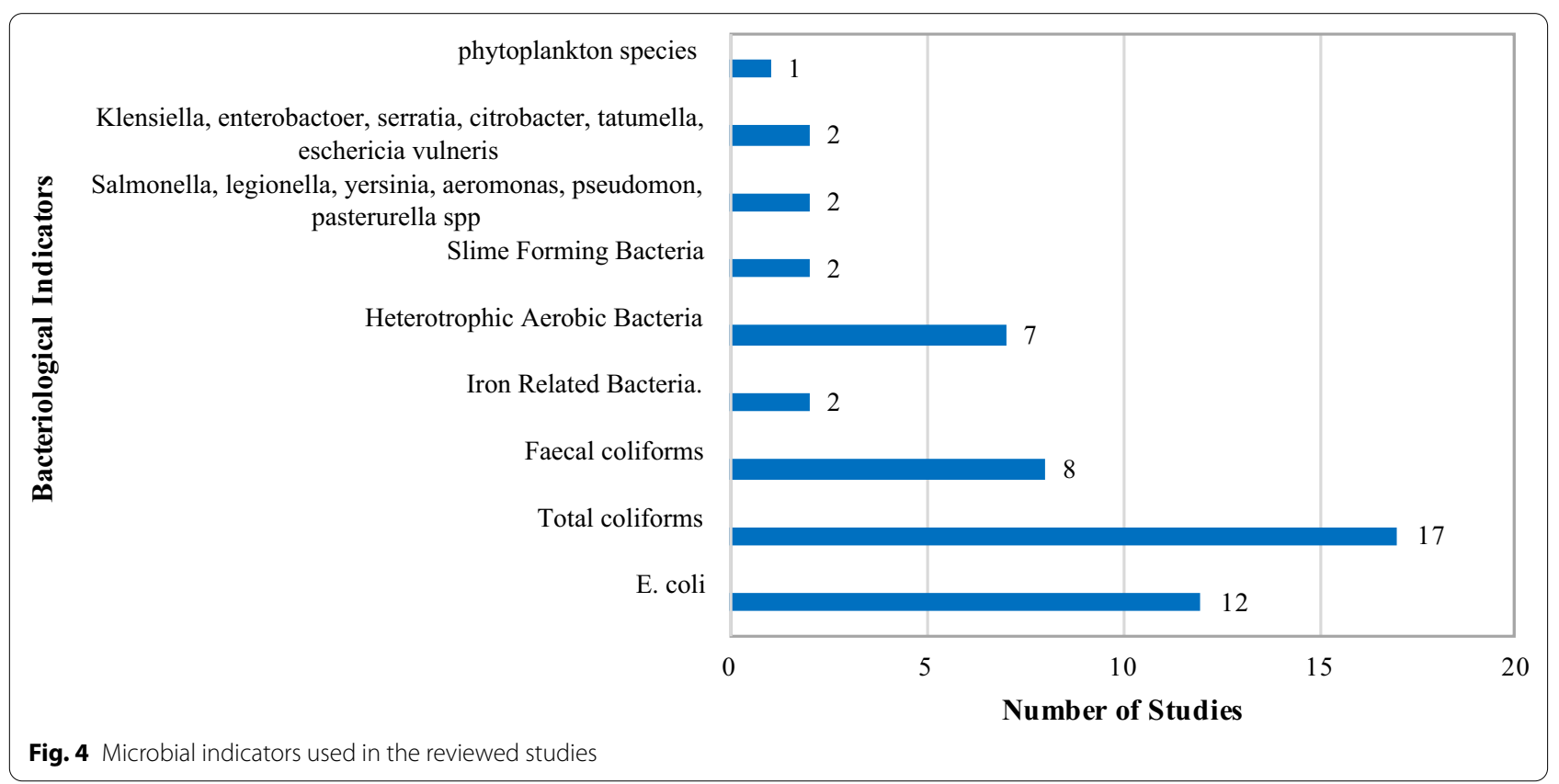


infection in developing countries was not investigated by the reviewed studies.

\section{Physicochemical indicators of stored water contamination}

These are physical and chemical aspects of water used in determining whether its quality is acceptable or not. Some of the common physicochemical contamination indicators that were used in characterising the quality of water in the studies reviewed included: $\mathrm{pH}$, Electrical Conductivity, Total Dissolved Solids, Total Suspended Solids, Turbidity, Temperature, Dissolved Oxygen, Iron $\mathrm{Fe}^{+}, \mathrm{Cu}, \mathrm{NO}_{3}{ }^{-}, \mathrm{PO}_{4}, \mathrm{Zn}, \mathrm{Cr}, \mathrm{Pb}, \mathrm{Zn}, \mathrm{K}, \mathrm{Mn}, \mathrm{Cl}$ (free and residual). $\mathrm{pH}$ was the most widely used parameter for physiochemical characterisation of stored water in the studies included in this review $(\mathrm{n}=12 ; 50 \%)$.

$\mathrm{pH}$ is paramount in checking the corrosiveness of water and the lower the $\mathrm{pH}$ the more corrosive the water, because of its acidic tendencies at low $\mathrm{pH}$ values (World Health Organization 2007). The water source, the material of the water storage tank or vessel, the temperature, mineral absorption, dust, the level of bacterial activity in a vessel, and the duration of water storage before use, affect the $\mathrm{pH}$ of water (Duru et al. 2013; Packiyam et al. 2016).

Electrical conductivity (EC) came second in frequency of use as a water quality indicator among the studies included in the review. 10 of the 24 (42\%) studies considered EC as a dependent variable, as there was a correlation between the level of Total Dissolved solids (TDS) and EC (see Fig. 5). This is depicted in the study conducted by Akuffo et al. (2013), where the EC value increased with an increase in the TDS value. About $38 \%$ of the reviewed 24 studies used TDS to describe the physicochemical nature of water stored (see Fig. 5). The esthetic quality of water in terms of colour is affected by the level of TDS (Oram 2020). The age and material of the tanks were found to affect the TDS of stored water (Nunes et al. 2018). However, no study of those included in this review undertook to determine the degree of correlation between the TDS and the EC. TDS has also been criticized as a poor parameter for measuring water quality as it does not detail the contents of the dissolved solids (Magnus 2019).

Heavy metals such as $\mathrm{Fe}^{+}, \mathrm{Cu}$, and $\mathrm{Mn}$ were also used in the assessment of water quality in $(n=6),(n=6)$, and $(n=5)$ studies, respectively (see Fig. 5). Heavy metals have an adverse effect when they accumulate in the human body as they can cause damage or reduce the mental central nervous function, lower energy levels, and damage body organs (Verma and Dwivedi 2013). $\mathrm{Fe}^{+}$ was seen predominantly in tanks that were made of steel and it was in high concentration where the tanks were relatively old (Al-Ghanim et al. 2014; Chia et al. 2013;
Chalchisa et al. 2017; Schafer and Mihelcic 2012; Nunes et al. 2018). The cleaning of the tanks also affects the concentration and accumulation of heavy metals. In a study by Ziadat (2005), it was noted that the level of heavy metals in water stored in tanks was elevated because the tanks were old and worn out, and had not been cleaned in a long time.

A study in Venezuela found temperature to be an important parameter of water quality because it affects the rate of microbial growth (Schafer and Mihelcic 2012). According to the same study, temperatures of $15{ }^{\circ} \mathrm{C}$ and/ or higher inside water storage tanks can cause significant bacterial growth. Other physicochemical indicators that were included in some of the of the reviewed studies were odour and taste (Duru et al. 2013; Varghese and Jaya 2008). Figure 5 shows the frequency of the key physicochemical indicators of water quality used in the studies reviewed.

\section{Water contamination in household tanks}

Due to intermittent water supply problems in many parts of the world, especially developing countries, water storage using tanks as well as small containers such as jerry-cans are commonly used by households to reserve water for use throughout the day. Rural communities use small containers that can easily be transported from the water sources to homes, while urban communities have piped water, therefore use water storage tanks to reserve water. There is a great deal of concern regarding in-house microbial contamination during handling and storage of water in developing countries (Akuffo et al. 2013).

Ziadat (2005) evaluated the impact of residential storage tanks on drinking water quality in comparison to its drinking water source, through analysis of major anions, cations, and heavy metals. It was found that the water in storage tanks had higher ionic concentrations compared to the sources. Rusting was suggested as a possible cause since most of the tanks had rusted. However, according to the $\mathrm{WHO}$, most chemicals arising in drinking water are of health concern only after extended years of exposure rather than months. The study by Graham and VanDerslice (2007) investigated the effectiveness of large household water storage tanks for protecting the quality of drinking water in El Paso County, Texas, and found that the water from the tanks was generally of poor quality. Longer storage periods of household water were noticed for households with large water tanks, which may have potentially increased the risk of contamination, and also led to chlorine volatilisation.

The study by Schafer and Mihelcic (2012) found that water storage impacts on water quality through storage tank material, which is most likely because of different water temperatures inside the tank. It was further found 


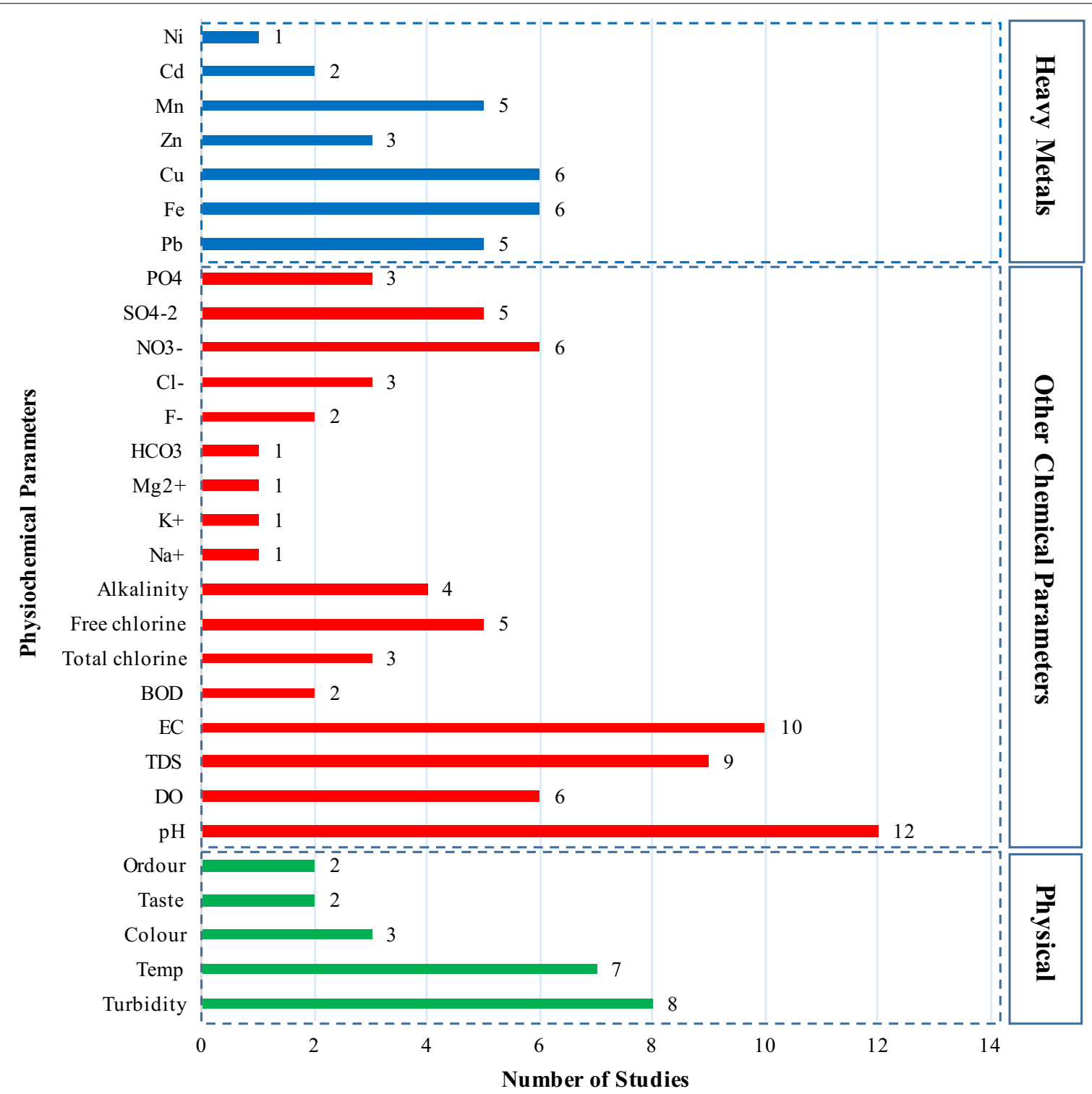

Fig. 5 Physicochemical indicators used in the studies reviewed

that storage tank designs can affect water quality if they do not allow the tanks to be completely emptied during use or cleaning. This may however not be an issue of tank design, but rather, the workmanship of the plumbers, because provisions for the outlets and washouts are usually made by manufacturers and the plumbers use these provisions to install the washouts and outlets depending on the size of pipes to be connected. Interestingly, the age of water storage tanks was found not to have any significant impact on water quality. However, a study by AlGhanim et al. (2014) contradicted this and suggested that the high levels of TDS in some tanks were as a result of the tanks being old.
A study conducted in Pakistan by Al-Ghanim et al. (2014) revealed that all tanks were contaminated with heterotrophic bacteria: $80 \%$ contained coliforms, 30\% contained fecal coliforms, but $E$. coli was not detected. It was also found that $60 \%$ of the tanks contained algal counts exceeding 103 unit/l. The study further revealed that different types of tank surfaces encouraged microbial growth differently. The quality of water in the different types of storage tanks was also investigated by Al-Bahry et al. (2013). Three types of water tanks were examined: glass-reinforced-plastic (GRP), polyethylene (PE), and galvanized iron (GI). Results showed that all water storage tanks supported microbial regrowth with high values 
of the microbial total count. Microbial regrowth varied with the type of the water storage tanks. Coliforms were isolated from all tanks but were abundantly found in GRP.

The study by Chalchisa et al. (2017) assessed the quality of drinking water in storage tanks in Ethiopia and found that water samples collected from drinking water storage tanks were positive for total coliforms and faecal coliforms. The result of this study showed that the drinking water was microbiologically contaminated in all sampling points. It was discussed that the high temperature after storage (up to $23.1{ }^{\circ} \mathrm{C}$ ) increased the number of faecal coliforms in storage tanks. All these studies confirm that water storage impacts the quality of water in many ways.

\section{Effects of household tank/vessel features on quality of stored water \\ Material of the water storage tank or vessel}

Various tank material types were found to be used in different regions from the literature reviewed as shown in Table 4. It is important to note that plastic tanks were widely used in the different regions compared to the rest of the tank materials. However, no explanation was given in the literature studied to justify the usage of the different tank materials, whether it was the cost, convenience, availability of the tank material, or climatic conditions of the regions.

Tank material was found to be a leading cause of water contamination. There was a variation in the frequency of microbial contamination relative to each type of water tank (Al-Bahry et al. 2013). Water storage tank materials, which are in direct contact with water can contribute contaminants from either the material used for tank construction/ production or from internal coatings used

Table 4 Tank used in different regions

\begin{tabular}{ll}
\hline Region & Tank type \\
\hline Al-Karack Province, Jordan & Galvanised steeel \\
Tiquipaya, Bolivia & Plastic \\
& Fiberglass \\
& Fiber cement \\
Muscat, Oman & Glass-reinforced-plastic \\
& Plastic \\
& Galvanized iron \\
Al-Kharj, Kingdom of Saudi Arabia & Fiberglass \\
& Plastic \\
& Galvanized steel \\
Jimma town, Ethiopia; Zaria, Nigeria; & Reinforced cement or concrete \\
Enugu, Nigeria; Accra, Ghana; El Paso & \\
County, Texas & \\
Kerala, India & Ferrocement \\
\hline
\end{tabular}

to protect the tank materials from contact with the water (Akuffo et al. 2013).

The studies conducted by Akuffo et al. (2013), Al-Bahry et al. (2013), Schafer and Mihelcic (2012) and Schafer (2010) all agreed that tank material affects water quality through temperature. This could be because different materials have different thermal conductivity, for instance, steel have a higher thermal conductivity and cools faster than plastic under the same weather condition. Additionally, different materials have different heat capacities. A steel tank of a given size absorbs more heat than a plastic tank of the same size. A comparison between fiberglass, fiber cement and black polyethylene tank materials, showed that temperatures are generally higher in the polyethylene tanks throughout the day than in fiberglass, and fiber cement tank materials (Schafer and Mihelcic 2012) (see Fig. 6). As such microbial activity is expected to be higher in the polyethylene tanks than in other tank materials.

When the temperature of the water reaches above 15 ${ }^{\circ} \mathrm{C}$, the occurrence of coliforms and heterotrophic bacteria is significantly higher (Khan and AlMadani 2016). An investigation conducted by Ogbozige et al. (2018) revealed that steel metal tanks have more EC than the plastic tanks, suggesting less mineral concentration in the steel metal tanks.

Different tank materials were also found to affect water quality because of the various unique features they possess (Table 5). For instance, Ziadat (2005) and Akuffo et al. (2013) found that heavy metals dissolve in water because of rusting. Plastic tanks allow certain types of bacteria to stick to the plastic surface and enable growth (Al-Ghanim et al. 2014). In the same vein, Jagals et al. (2003) and Al-Bahry et al. (2013) found that tank surfaces allow the growth of biofilm. Biofilms provide a variety of microenvironments for microbial regrowth (Al-Bahry et al. 2013). These films break loose from the sides especially during filling with no subsequent rinsing and form particulate suspensions in water which harbour significant numbers of viable bacteria (Jagals et al. 2003). This could be a major cause of water contamination particularly in developing countries because of the rampant intermittent water supply issues, which result into frequent emptying and refilling of water storage tanks, thus causing dislodging of biofilm into stored water. However, a comparison of the levels of biofilm formation on the different water storage tank materials has not been investigated to-date.

In a study by Mohanan, et al. (2017) it was concluded that conventional water storage vessels such as copper, brass, and clay possessed antimicrobial activity and were highly efficient against pathogenic bacteria than vessels made up of plastic, steel, and aluminium. In some other 


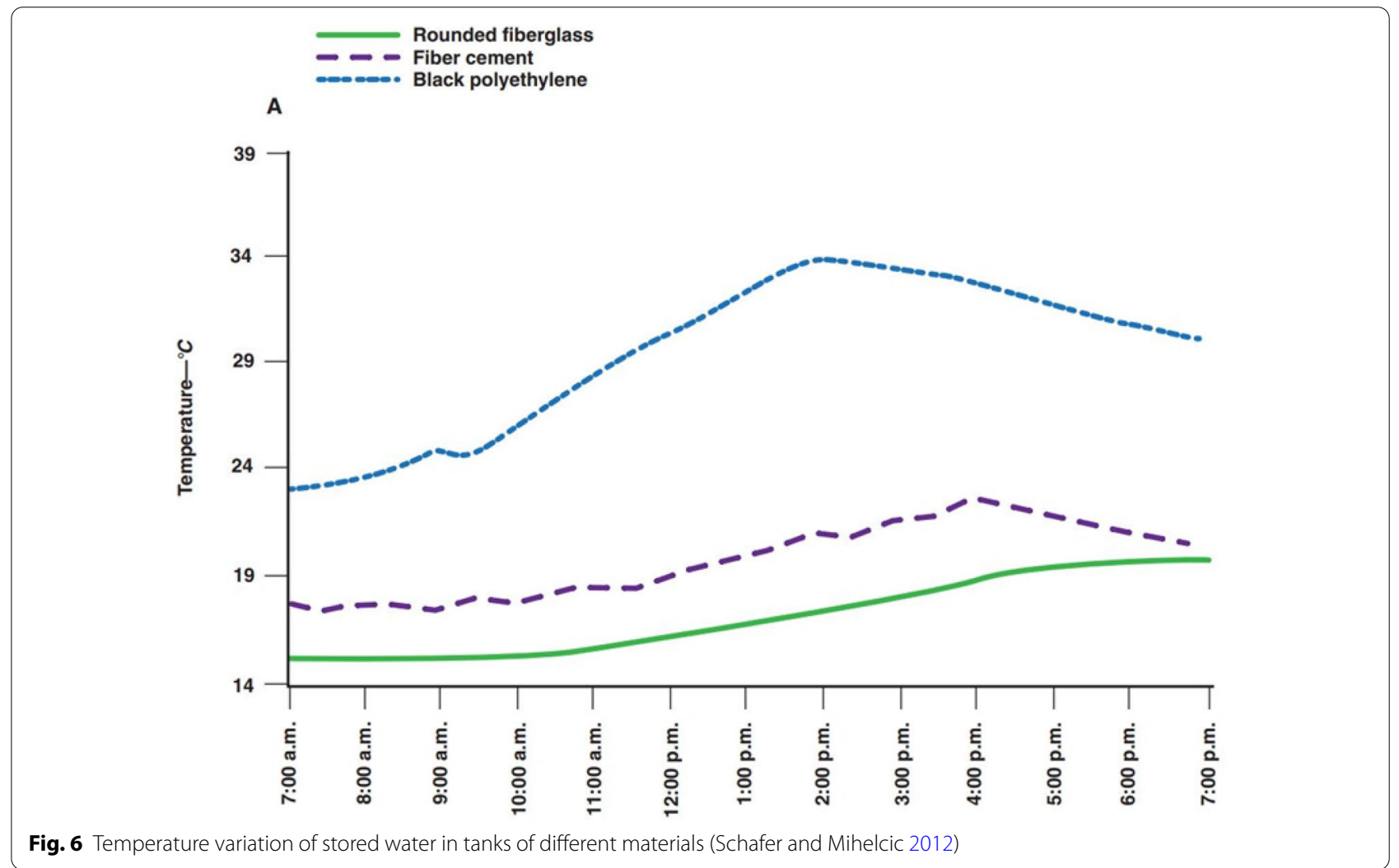

reviewed studies, there were contradictory findings on the contamination levels of the different water storage tank/vessel materials. For instance, Al-Bahry et al. (2013) found that glass-reinforced plastic (GRP) tanks contained the most contaminated water, and polyethylene (PE) tanks contained the least contaminated water. However, Schafer and Mihelcic (2012) found that PE tanks contained the most contaminated water while GRP tanks contained the least contaminated water. These results could, however, be attributed to other variables that may not have been investigated in these studies. These discrepancies demand further research to determine which materials are best suitable for household water storage. Table 4 shows the studies that focused on the different tank/vessel material and the corresponding values of water quality indicators as per the studies.

\section{Residence/storage time}

Tank size and capacity do have an effect on water quality. This is effect is realized through retention or residence time. Microbial growth increases as residence time increases (Schafer 2010). Previous studies such as Agensi et al. (2019) and Chia et al. (2013) found a significant associations between the duration of water storage and the level of contamination. For instance, Nnaji et al. (2019) found an average E. coli, total coliforms, and enterococci count of 3,4 , and $3 \mathrm{MPN} / 100 \mathrm{ml}$ on the first day and 8,69 , and $114 \mathrm{MPN} / 100 \mathrm{ml}$ respectively on the 35th day of water storage; heterotrophic plate count (HPC) of $5 \mathrm{CFU} / \mathrm{ml}$ on the 1 st day and $31 \mathrm{CFU} / \mathrm{ml}$ on the 35th day of storage.

The study by Ogbozige et al. (2018) investigated the effect of storage duration on water quality in different material containers. The study revealed that the maximum retention period for storing water in all the container materials studied as inferred from the water quality was about 21 days, except for clay-pot material where the study showed that its retention period should not exceed 6 days; however, the uncoated steel metal tank was not recommended. It was concluded that black plastic containers preserved water quality better during storage, compared to coloured plastic containers, galvanized iron or coated steel containers, and clay pots.

Large storage tanks allow for longer water storage periods, which may potentially increase the risk of contamination and chlorine volatilisation (Graham and VanDerslice 2007). However, a factor that has not been well investigated by any of the reviewed studies is the fact that the residence time also depends on the household size and per capita water usage. A large tank serving a large household size or a small tank serving a small household size, both with high per capita water use, implies that the 
Table 5 Different tank/vessel material and the corresponding values of water quality indicators as per the studies

\begin{tabular}{|c|c|c|c|c|c|c|c|}
\hline \multirow[t]{2}{*}{ Author (Year) } & \multirow[t]{2}{*}{ Indicator } & \multicolumn{6}{|c|}{ Major tank/vessel material } \\
\hline & & Polyethylene (PE) & $\begin{array}{l}\text { Glass- } \\
\text { reinforced } \\
\text { plastic (GRP) }\end{array}$ & $\begin{array}{l}\text { Galvanized } \\
\text { iron (GI) }\end{array}$ & Fiber cement & Steel metal & Glass \\
\hline \multirow[t]{2}{*}{ Al-Bahrya et al. (2013) } & TC (cfu/ml) & 6 & 11.5 & 11 & & & \\
\hline & THPC (cfu/ml) & 7 & 7.5 & 11 & & & \\
\hline \multirow[t]{6}{*}{ Akuffo et al. (2013) } & TC (cfu/100ml)-mean & 2.31 & & & & 2.18 & \\
\hline & FC (cfu/100ml)-mean & 65.2 & & & & 49.2 & \\
\hline & $\mathrm{pH}$-mean & 7.59 & & & & 7.6 & \\
\hline & $\mathrm{EC}(\mu \mathrm{S} / \mathrm{cm})-$ mean & 102 & & & & 109 & \\
\hline & TDS-mean & 66.8 & & & & 65.1 & \\
\hline & Turbidity (NTU)-mean & 4.83 & & & & 7.58 & \\
\hline \multirow[t]{6}{*}{ Schafer and Mihelcic (2012) } & TC (mpn)-mean & 146 & 147 & & 295 & & \\
\hline & E. coli (mpn)-mean & 33 & 26 & & 14 & & \\
\hline & pH-mean & 6.82 & 7.05 & & 6.93 & & \\
\hline & $\mathrm{EC}(\mu \mathrm{S} / \mathrm{cm})$-mean & 0.173 & 0.193 & & 0.185 & & \\
\hline & TDS-mean & 0.1 & 0.1 & & 0.1 & & \\
\hline & Turbidity (NTU)-mean & 4.8 & 6.2 & & 4 & & \\
\hline \multirow[t]{7}{*}{ Duru et al. (2013) } & $\mathrm{TC}(\mathrm{cfu} / \mathrm{ml})$ & 300 & & & & 800 & 200 \\
\hline & $\mathrm{FC}(\mathrm{cfu} / \mathrm{ml})$ & 200 & & & & 500 & 100 \\
\hline & THB (cfu/ml) & 13,000 & & & & 14,000 & 12,000 \\
\hline & pH-mean & 6.25 & & & & 6.09 & 6.25 \\
\hline & $\mathrm{EC}(\mu \mathrm{S} / \mathrm{cm})-$ mean & 0.002 & & & & 0.003 & 0.002 \\
\hline & TDS-mean & 0.003 & & & & 0.005 & 0.003 \\
\hline & Turbidity (NTU)-mean & 1.96 & & & & 1.98 & 1.96 \\
\hline \multirow[t]{4}{*}{ Mohanan et al. (2017) } & THPC (cfu/ml) & 269 & & & & 300 & 395 \\
\hline & $\mathrm{pH}$-mean & 13 & & & & 10 & 9.8 \\
\hline & $\mathrm{EC}(\mu \mathrm{S} / \mathrm{cm})$-mean & 122.5 & & & & 125.7 & 126.9 \\
\hline & TDS-mean & 40 & & & & 60 & 70 \\
\hline \multirow[t]{3}{*}{ Ogbozige et al. (2018) } & THB (cfu/100ml)-mean & 6700 & & & & 93 & \\
\hline & pH-mean & 7.10 & & & & 7.25 & \\
\hline & EC $(\mu \mathrm{S} / \mathrm{cm})$-mean & 403.53 & & & & 386.76 & \\
\hline
\end{tabular}

TC total coliforms, FC faecal coliforms, THPC total heterotrophic plate count, THB total heterotrophic bacteria, TDS total dissolved solids

water residence time in the tank is very short, and thus it is less likely to get contaminated during storage. Conversely, a large tank serving a small household size with low per capita water use, may result into longer water residence time in the tank, and hence potentially more contamination during storage may be witnessed.

In the study by Al-Bahry et al. (2013) it was noted that the water distribution system started with low microbial contamination. However, when water was transferred to storage tanks, microbial contamination spread rapidly due to water stagnation. Static water is undesirable because this condition provides an opportunity for the suspended particles to settle in the tank as sediments and later stick on the sides of the tank. There is a need for further research on this phenomenon because it may also be argued that the biological and physical chemical contamination per unit of water in large tanks may be lower as compared to that in small tanks based of the amount of time the water is stagnant in the different tank sizes, given a constant number of users for all the tanks.

\section{Tank/vessel age, colour, design, and location}

These four tank/vessel features were investigated by only a few studies; each was investigated by either one or two studies.

Tank age While Chia, et al. (2013) found a significant relationship between the age of the water storage tanks and the occurrence of a significant number of the pathogen species, Schafer and Mihelcic (2012) found no meaningful effect of tank age on water quality. The argument was that tanks that well-maintained tanks do not affect water quality even after many years of use. Proper maintenance ensures that undesirable conditions such as biofilm, rusts, broken covers, etc. are 
removed or restored to good conditions, enabling tanks to maintain good water quality.

Tank colour Chia et al. (2013) found that the colour of the tanks had a significant association with physicochemical parameters such as dissolved oxygen and biological oxygen demand, which also determined the occurrence and abundance of 9 (including 2 cyanobacteria) out of the 13 species reported in the study. Water storage tank colour may also affect water quality through temperature, since different colours absorb heat to varying extents, affecting the temperature of the water in the tanks differently. Darker colours absorb more heat than lighter colours. However, dark-coloured (plastic) tanks are more commonly used than light coloured tanks, especially in developing countries. Schafer (2010) found black polyethylene among the most common types of tanks in Bolivia. Chia et al. (2013) had a third of the water storage tanks investigated in Nigeria as black. In the same vein, the storage tanks provided by the government in El Paso County, Texas, USA and investigated by Graham and VanDerslice (2007) were also dark in colour. This could be further affecting water quality because high temperatures encourage bacteria growth as discussed above in the section of "Material of the water storage tank or vessel".

Tank design This study review revealed that tank design affects water indirectly by affecting user practices. A study by Schafer (2010) reported that increased microbial growth in household storage tanks compared to water sources may be due to the design of household storage tanks, which sometimes complicates the complete emptying of the storage tank while in use or during washouts. However, the challenge of completely emptying the water storage tanks may also be attributed to the wrong pipe configuration of outlet and washout pipes on the tanks - as a result of poor workmanship of plumbers.

Tank location This affects water quality through temperature. In the study by Schafer (2010), the temperature of water in a black polyethylene tank was high when the tank was positioned under direct sunlight, but the temperature of water dropped when the tank was covered by a shade of a wall; while the temperature of water in a fibreglass tank continued to rise because it remained under direct sunlight. Bacterial growth would therefore be expected to be higher in the fiberglass tank than the black polythene tank. However, as earlier discussed in this same section under 'colour', a black tank absorbs more heat than lightly coloured tanks. The same study found that the temperature of water in the black polyethylene tank remained higher than that of the other types of tanks throughout the day, including the period when it was under the shade.

\section{Effects of user practices on quality of household tank/ vessel stored water \\ Tank/vessel covering}

Water storage tanks have an impact on the water quality if they are not handled in hygienic ways such as sealing or covering of the storage tanks (Chalchisa et al. 2017; Akuffo et al. 2013). Lack of tank covers, potentially increases the risk of contamination of stored water with animal and bird faeces, as well as dust and airborne particulates. This facilitates the growth of algae when the tanks are exposed to sunlight, and lead to undesirable changes in the taste, odor, and color of water (Al-Ghanim et al. 2014). Only a few of the reviewed studies investigated tank covering. There may be other implications of tank covering that were not investigated by the reviewed studies. For instance, if an elevated tank supplied by municipal water and located outside a house is not covered, rainwater my fall into the tank and thus increase the volume of water in the tank. Consequently, this would reduce the residual chlorine of the stored water.

\section{Tank/vessel cleaning}

Cleaning practices of water storage tank/vessel have impact on household water quality. Several studies did investigate tank cleaning (Rodrigo et al. 2010; Lévesque et al. 2008; Jagals et al. 2003; Schafer 2010; Nnaji et al. 2019). The study by Jagals et al. (2003) found that biofilm-like substances could build up in storage tanks or containers (especially in those not regularly cleaned), which could contribute to hazardous microbiological contamination of container-stored drinking water, especially if particles from the film become dislodged into, and ingested with the water. In a study by Lévesque et al. (2008), the effect of tank cleaning on water quality was investigated and the results showed that the contamination levels were almost the same for water tanks that had not been cleaned in a range of three years (2000 to 2002), but the contamination had strongly reduced in the year 2003 when the cleaning was carried out. Similarly, the study by Pesewu, et al. (2014) found that the recent cleaning of three (3) polyethylene tanks was responsible for lowering their total coliform and faecal coliform counts.

The study Schafer and Mihelcic (2012) found that the cleaning frequency of tanks impacts the quality of water in the storage tanks. The study found that storage tanks cleaned three (3) or more times per year had lower $E$. coli counts and turbidity than storage tanks cleaned less frequently (Table 6). The study by Chia et al. (2013) suggested that possible means of continuous contamination and recontamination that encourage the growth or re-growth of microalgae and cyanobacteria in the water storage tanks include inadequate periodic cleaning or scrubbing of the tanks. The study by Nnaji et al. (2019) 
Manga et al. Environ Syst Res

(2021) $10: 18$

Page 23 of 26

found that total coliforms, enterococci, HPC, and E. coli counts increased with an increase in the intervals of regular cleaning as shown in Fig. 7; Table 6.

The study by Akuffo, et al.,(2013) also found that ertain types of tanks (earthen) had less degree of contamination compared with other types (polyethylene and metal tanks) because among other reasons, they were cleaned more frequently. In Al-Ghanim, et al., (2014), it was found that $80 \%$ of the tanks were not frequently cleaned, and therefore contained contaminated water. It can clearly be seen that results from the various studies do agree that cleaning practices of water storage tanks have a significant effect on the stored quality of water. However, the recommended cleaning frequency is still unclear.

Limitation of the study

This study only focused on studies written in the Englis language and there was no inclusion of studies or records made in other languages. As such, non-English studies that would provide knowledge on the subject studied may have been missed out. Also, the selection of grey literature was limited to theses and publications from accredited institutions and organizations, and thus
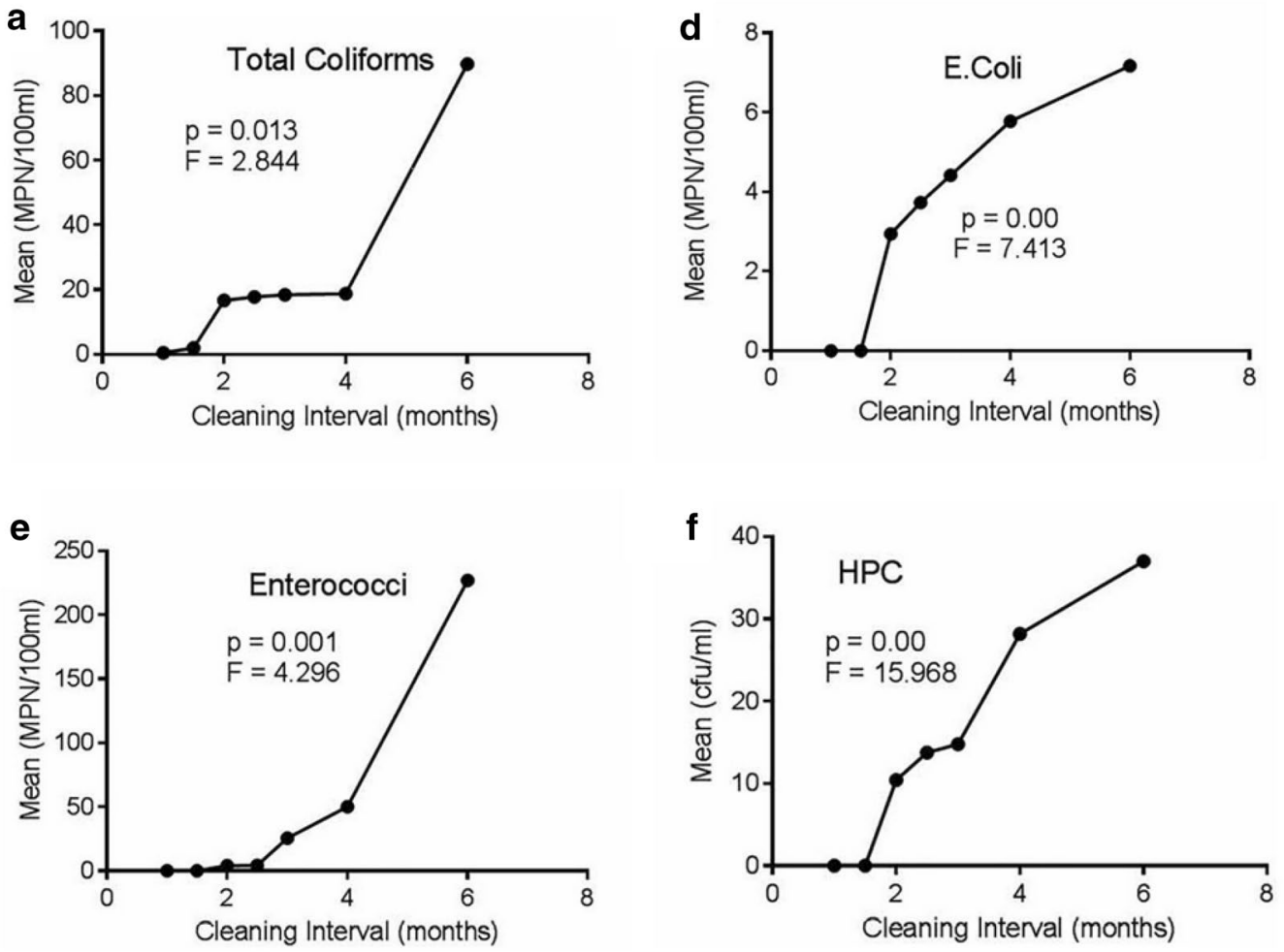

Fig. 7 Effect of tank cleaning on the bacteriological quality of water (Adopted after Nnaji et al. (2019))

Table 6 Water quality at different cleaning frequencies as shown in $\mathbf{2}$ reviewed studies

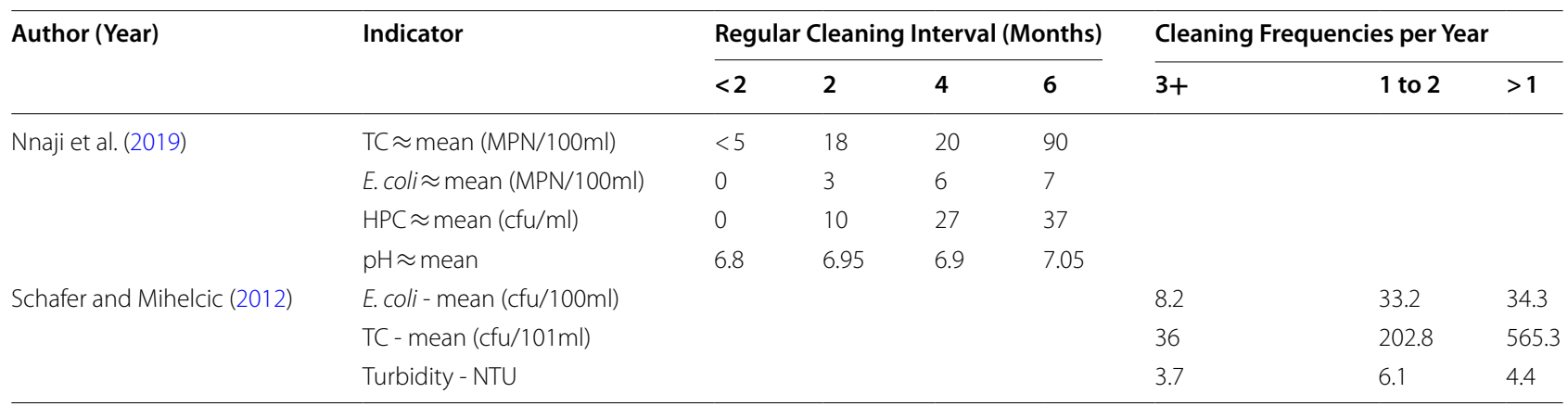


there is a likelihood that some data may not have been captured from all the available grey literature.

\section{Conclusions and recommendations}

The objective of this study was to identify what water storage tank features and user practices affect water quality, how they affect water quality, and recommendations on how their effect can be mitigated. A systematic literature review was conducted to answer these questions. The identified features of water storage tanks that affect water quality include tank/ vessel material, colour, design, location, and retention time. The pronounce user practices that was seen to affect the water quality in storage tanks/vessels were cleaning; and covering. This study suggests tank/vessel material and retention time of water in tanks/ vessels as the key features that had the highest impact on water quality. However, there is a contradiction regarding the most suitable material to curb bacteriological contamination. Further research is recommended to expressly determine the tank/ vessel material that is best suited for bacteriological and physiochemical contamination.

While the practice of tank cleaning was seen to affect water quality, there is a need to carry out research to determine the optimal cleaning frequency of the storage tanks or vessels that guarantees safe drinking water quality. Additionally, use of proper cleaning methods and tools; reduction of water storage periods by using tank sizes that match the number of household members and per capita water use; covering tanks/vessels; treatment of water at the household level for instance by boiling or chlorination; regular maintenance of storage tanks/ vessels including replacement of old tanks; community education, adoption, and promotion of appropriate water safety plans; use of light-coloured tanks/vessels; improvement of tank design to ease cleaning and maintenance; and locating tanks under shades are some of the measures that can significantly reduce contamination or pathogens in the stored household water, and improve household water quality.

Tank/ vessel cleaning was the most investigated practice, but there is a need to investigate other user practices that are envisaged to affect water quality like mixing water from different sources in storage vessels and chlorination or treatment of water in the storage vessel. Comprehensive inclusive studies should be conducted to assess the effect of other user practices on stored water quality, involving key informant interviews, surveys, and experimental tests with large samples to enhance the reliability of data, ensure dissemination of information, contribute to feasible recommendations and implementation of interventions.
A multivariate contamination prediction model should be developed combining all the tank/ vessel features and maintenance/ user practices to determine the best matrix for safe storage of water at the household level. In addition, comparison of the economic implications of choosing different tank types through life cycle costing and cost benefit analysis would be useful.

\section{Abbreviations \\ Al: Aluminium; As: Arsenic; BOD: Biochemical oxygen demand; Ca: Calcium; Cd: Cadmium; Cl: Chlorine; Cr: Chromium; Cu: Copper; DO: Dissolved oxygen; EC: Electrical conductivity; E. coli: Escherichia coli; Fe' ${ }^{+}$Flouride; F-: Iron; GRP: Glass reinforced plastic; HPC: Heterotrophic plate counts; K: Potassium; Mg: Magnesium; Mn: Manganese; MPN: Most probable number; Na: Sodium; $\mathrm{NO}_{3}^{-}$: Nitrates; Ni: Nickel; $\mathrm{SO}_{4}$ : Sulfate/sulphate ion; SDG: Sustainable develop- ment goals; TDS: Total dissolved solids; TSS: Total suspended solids; Pb: Lead; PE: Polyethylene; $\mathrm{PO}_{4}$ : Phosphates; THPC: Total heterotrophic plate count; WHO: World Health Organization; Zn: Zinc.}

\section{Acknowledgements}

We acknowledge all the reviewers and the GIS expert Ms. Atuhaire Christine for the tremendous work done during this study and all the team members that contributed to this article.

\section{Authors' contribution}

MM, LO and TGN conceived and designed the review. TGN, LO, MM, PA, and $\mathrm{HN}$ extracted the data from the literature. MM, TGN, and LO summarized the data in tabular and graphical form and wrote the manuscript. NK, IN, and EK provided comments and feedback on the interpretation of the results and reviewed the manuscript. MM acquired funding. All authors read and approved the final manuscript.

\section{Funding}

This research was funded by Makerere University Research and Innovation Fund under grant [RIF 1/CEDAT/010]. This review paper constitutes a part of the research project on examining the effect household water storage tanks/vessel features and related user practices on the quality of water. This study helped in identifying gaps in literature that could culminate in further research.

\section{Availability of data materials}

Not Applicable. There are no linked research data sets for this review as no data was used for the research described in the manuscript.

\section{Ethics approval and consent to participate}

Not applicable.

\section{Consent for publication \\ Not applicable.}

\section{Competing interests}

The authors declare that there is no conflict of interest regarding the publication of this paper.

\section{Author details \\ ${ }^{1}$ Department of Construction Economics and Management, School of the Built Environment, Makerere University, P.O. Box 7062, Kampala, Uganda. ${ }^{2}$ The Water Institute at UNC, Department of Environmental Sciences and Engi- neering, Gillings School of Global Public Health, University of North Carolina at Chapel Hill, Chapel Hill, NC, USA. ${ }^{3}$ Department of Civil Engineering, Faculty of Engineering, Ndejje University, P.O. Box 7088, Kampala, Uganda. ${ }^{4}$ National Water and Sewerage Corporation, P.O. Box 7053, Kampala, Uganda.}

Received: 7 December 2020 Accepted: 2 February 2021

Published online: 22 February 2021 


\section{References}

Agensi A, Tibyangye J, Tamale A, Agwu E, \& C. Amongi., 2019. Contamination Potentials of Household Water Handling and Storage Practices in Kirundo Subcounty, Kisoro District, Uganda. Journal of Environmental and Public Health, pp. 1-8

Akuffo I, Cobbina S, Alhassan E, Nkoom M (2013) Assessment of The quality of water before and after storage. Ghana Int J Sci Technol Res 2(2):221-227

Al-Bahry SN, Elshafie AE, Victor R, Mahmoud IY, Al Hinai JA (2011) Opportunistic pathogens relative to physicochemical factors in water storage tank. J Water Health Issue 9:382-393

Al-Bahry S, Al-Hinai J, Mahmoud I, Al-Musharafi S (2013) Opportunistic and microbial pathogens in municipal water distribution systems. APCBEE Proc 5:339-343

Al-Bahry SN, Mahmoud IY, Al-Khaifi A, Elshafie AE, Al-Harthy A (2009) Viability of multiple antibiotic resistant bacteria in distribution lines of treated sewage effluent used for irrigation. Water Sci Technol Issue 60:2939-2948

Al-Ghanim K, El-Sala A, Mahboob S (2014) Assessment of water quality for some roof tanks in Alkharj governorate. KSA Pakistan J Zool 46(4):1003-1012

Anthonj C, Setty KE, Ezbakhe F, Manga M, Hoeser C (2020) A systematic review of water, sanitation and hygiene among Roma communities in Europe: Situation analysis, cultural context, and obstacles to improvement. Int J Hyg Environ Health 226:113506

Boretti A, L., Rosa., (2019) Reassessing the projections of the World Water Development Report. Clean Water 2:1

Chalchisa D, Megersa M, Beyene A (2017) Assessment of the quality of drinking water in storage tanks and its implication on the safety of urban water supply in developing countries. Environ Syst Res 6:1

Chia M, Oniye S, Swanta A (2013) Domestic water quality assessment: microalgal and cyanobacterial contamination of stored water in plastic tanks in Zaria, Nigeria. Eur J Sci Res 110(4):501-510

Colicchia C, Strozzi F (2012) Supply chain risk management: a new methodology for a systematic literature review. Supply Chain Manag 17(4):403-418

Doctor DIY (2021) Cold water systems including indirect and direct systems found in your home. https://www.diydoctor.org.uk/projects/direct-indir ect-cold-water-systems.htm. Accessed 7 Jan 2021.

Douhri H, Raissouni I, Tazi S, Badia D (2015) Effect of house storage on water's quality in rural areas of Tangier-Tetuan Region (Morocco). Larhyss J 24:301-314

Duru M, Amadi C, Amadi B, Nsofor C, Humphrey N (2013) Effect of different storage vessel on water quality. Global Res J Sci 2:9-13

Fleming L, Anthonj C, Thakkar MB, Tikoisuva WM, Manga M, Howard G, Shields KF, Kelly E, Overmars M, Bartram J (2019) Urban and rural sanitation in the Solomon Islands: how resilient are these to extreme weather events? Sci Total Environ 683:331-340

Geldreich E (1978) Bacterial populations and indicator concepts in feces, sewage, stormwater and solid wastes. In Indicators of Viruses in Water and Food (ed.), Ann Arbor Science, p. 51-97

Graham J, VanDerslice J (2007) The effectiveness of large household water storage tanks for protecting the quality of drinking water. J Water Health 5(2):307-313

Harden A (2010) Mixed-Methods Systematic Reviews: Integrating Quantitative and Qualitative Findings.National Center for the Dissemination of Disability Research. Focus Technical Brief No. 25. Austin, TX. http://ktdrr.org/ ktlibrary/articles_pubs/ncddrwork/focus/focus25/Focus25.pdf. Accessed 25 Jan 2020

Heale R, Twycross A (2015) Validity and reliability in quantitative studies. Evid Based Nurs 18(3):66-67

Holt S (2005) A survey of water storage practices and beliefs in households in Bonao, Dominican Republic in 2005. Springer, Berlin

Jack L, Hayes SC, Scharalda JG, Stetson B, Jones-Jack NH, Valliere M, Kirchain WR, LeBlanc C (2010) Appraising quantitative research in health education:guidelines for public health educators. Health Promot Pract 11(2):161-165

Jagals P, Jagals C, Bokako T (2003) The effect of container-biofilm on the microbiological quality of water used from plastic household containers. J Water Health 1(3):101-108

Khan M, AlMadani A (2016) Assessment of microbial quality in household water tanks in Dubai. United Arab Emirates Environ Eng Res 22(1):55-60

Lévesque B, Pereg D, Watkinson E, Maguire J, Bissonnette L, Gingras S, Rouja P, Bergeron M, Dewailly É (2008) Assessment of microbiological quality of drinking water from household tanks in Bermuda. Can J Microbiol 54(6):495-500

Loevinsohn B (1990) Health education Interventions in developing countries: a methodological review of published articles. Int J Epidemiol 19(4):788-794

Magnus (2019) Why TDS is a poor measure of water quality. https://tappwater. co/en/tds-tap-water-filter-quality/. Accessed 25 Jan 2020

Majuru B, Suhrcke M, Hunter PR (2016) How do households respond to unreliablewater supplies? A systematic review. Int J Environ Res Public Health 13(12):1222

Manga M, Bartram J, Evans B (2020) Economic cost analysis of low-cost sanitation technology options in informal settlement areas (case study: Soweto, Johannesburg). Int J Hygiene Environ Health 223(1):289-298

Mohanan N, Manju E, Sonia J (2017) The effect of different types of storage vessels on water quality. Int J Innov Res Sci Eng Technol 6(10):20362-20368

Nakagiri A, Niwagaba CB, Nyenje PM, Kulabako RN, Tumuhairwe JB, Kansiime F (2016) Are pit latrines in urban areas of sub-Saharan Africa performing? A review of usage, filling, insects and odour nuisances. BMC Public Health 16:120

Nnaji C, Nnaji I, Ekwule R (2019) Storage-induced deterioration of domestic water quality. J Water Sanit Hyg Dev 9(2):329-337

Nunes L, Oliveira M, de Souza A, Lopes L, Dias P, Nogueira G, Souza M (2018) Water quality comparison between a supply network and household reservoirs in one of the oldest cities in Brazil. Int J Environ Health Res 29(2):173-180

Ogbozige F, Ibrahim F, Adie D (2018) Effect of storage time and container material on potable water quality. Life J Sci Technol 1(2):59-71

Oram BP (2020) Water Research Center-total dissolved solids drinking water quality. https://water-research.net/index.php/water-treatment/tools/total -dissolved-solids. Accessed 25 Jan 2020

Packiyam R, Kananan S, Pachaiyappan S, Narayanan U (2016) Effect of storage containers on coliforms in household drinking water. Int J Curr Microbiol Appl Sci 5(1):461-477

Pesewu G, Norshie Venus, Boakye Nana, Olu-Taiwo Michael, Adjei David, MillsRobertson Felix, Osei-Djarbeng Samuel, Asmah R, Ayeh-Kumi P (2014) Bacteriological assessment of the quality of water stored in household poly tanks in student hostels in the Korle-Bu Teaching Hospital, Accra, Ghana. Int J Med Sci Clin Invent 1:194-202

Pluye P, Gagnon MP, Griffiths F, Johnson-Lafleur J (2009) A scoring system for appraising mixed methods research, and concomitantly appraising qualitative, quantitative and mixed methods primary studies in mixed studies reviews. Int J Nurs Stud 46(4):529-546

Puzzolo E, Stanistreet D, Pope D, Nigel B, Rehfuess E (2013) Factors influencing the largescale uptake by households of cleaner and more efficient household energy technologies. London: EPPI-Centre, Social Science Research Unit, Institute of Education, University of London.

Raju N, Roopavathi C, Ramachandra K, Niranjana SR (2011) Assessment of coliform contamination in drinking water from source to point of use in Mysore city of Karnataka, India. pp. 1-6

Rodrigo S, Sinclair M, Leder K (2010) A survey of the characteristics and maintenance of rainwater tanks in urban areas of South Australia. Water Sci Technol 61(6):1569-1577

Schafer C (2010) Impact of tank material on water quality in household water storage systems in Cochabamba, Bolivia. Springer, Berlin

Schafer C, Mihelcic J (2012) Effect of storage tank material and maintenance on household water quality. J Am Water Work Assoc 104(9):E521-E529

Spencer L, Ritchie J, Lewis J, Dillon L (2003) Quality in qualitative evaluation: a framework for assessing research evidence. National Center for Social Research, London

Thomas B, Ciliska D, Dobbins M, Micucci S (2004) A process for systematically reviewing the literature: providing the research evidence for public health nursing interventions. World views Evid Based Nurs 1(3):176-184

Varghese J, Jaya D (2008) Drinking water quality assessment of rain water harvested in ferrocement tanks in Alappuzha District, Kerala (India). J Environ Sci Eng 50(2):115-120

Venkataramanan V, Crocker J, Karon A, Bartram J (2018) Community-led total sanitation: a mixed-methods systematic review of evidence and its quality. Environ Health Persp 126(2):1-17

Verma R, Dwivedi P (2013) Heavy metal water pollution: a case study. Recent Res Sci Technol 5:98-99 
World Bank (2019) Worsening Water Quality Reducing Economic Growth by a Third in Some Countries: World Bank. https://www.worldbank.org/ en/news/press-release/2019/08/20/worsening-water-quality-reducingeconomic-growth-by-a-third-in-some-countries. Accessed 23 January 2020

World Health Organization (2007) pH in Drinking-water: Revised background document for development of WHO Guidelines for Drinking-water

Quality. https://www.who.int/water_sanitation_health/dwq/chemicals/ ph_revised_2007_clean_version.pdf. Accessed 25 January 2020]
Ziadat A (2005) Impact of storage tanks on drinking water quality in Al-Karak Province-Jordan. J Appl Sci 5(4):634-638

\section{Publisher's note}

Springer Nature remains neutral with regard to jurisdictional claims in published maps and institutional affiliations.

\section{Submit your manuscript to a SpringerOpen ${ }^{\circ}$ journal and benefit from:}

- Convenient online submission

- Rigorous peer review

- Open access: articles freely available online

- High visibility within the field

- Retaining the copyright to your article

Submit your next manuscript at $\boldsymbol{\nabla}$ springeropen.com 